\title{
Salicylic Acid Is Involved in the Nb-Mediated Defense Responses to Potato virus $X$ in Solanum tuberosum
}

\author{
Gerardo Sánchez, ${ }^{1}$ Nadia Gerhardt, ${ }^{1}$ Florencia Siciliano, ${ }^{1}$ Adrián Vojnov, ${ }^{2}$ Isabelle Malcuit, ${ }^{3}$ and \\ María Rosa Marano' \\ ${ }^{1}$ Instituto de Biología Molecular y Celular de Rosario (IBR-CONICET), Área Virología, Facultad de Ciencias Bioquímicas \\ y Farmacéuticas, Universidad Nacional de Rosario, Suipacha 531, 2000, Rosario, Argentina; ${ }^{2}$ Fundación Pablo Cassará, \\ Saladillo 2468 C1440FFX, Ciudad de Buenos Aires, Argentina; ${ }^{3}$ Algentech Ltd, Institute of Food Research, Norwich \\ Research Park, Norwich NR4 7UA, U.K.
}

Submitted 2 April 2009. Accepted 7 December 2009.

To evaluate the role of salicylic acid $(\mathrm{SA})$ in $N b$-mediated hypersensitive resistance to Potato virus $X$ (PVX) avirulent strain ROTH1 in Solanum tuberosum, we have constructed SA-deficient transgenic potato plant lines by overexpressing the bacterial enzyme salicylate hydroxylase (NahG), which degrades SA. Evaluation of these transgenic lines revealed hydrogen peroxide accumulation and spontaneous lesion formation in an age- and light-dependent manner. In concordance, $N a h G$ potato plants were more sensitive to treatment with methyl viologen, a reactive oxygen speciesgenerating compound. In addition, when challenged with PVX ROTH1, NahG transgenic lines showed a decreased disease-resistance response to infection and were unable to induce systemic acquired resistance. However, the avirulent viral effector, the PVX 25-kDa protein, does induce expression of the pathogenesis-related gene $P R-1 a$ in $N a h G$ potato plants. Taken together, our data indicate that $\mathrm{SA}$ is involved in local and systemic defense responses mediated by the $N b$ gene in Solanum tuberosum. This is the first report to show that basal levels of $\mathrm{SA}$ correlate with hypersensitive resistance to $\mathrm{PVX}$.

Plants have evolved a variety of sophisticated mechanisms for defending themselves against microbial pathogen infection. The recognition of a pathogen-encoded effector by host resistance $(\mathrm{R})$ proteins triggers disease resistance, which usually manifests as a hypersensitive cell death response (HR) at the site of pathogen infection (Greenberg and Yao 2004). HR occurs locally and leads to long-term resistance in surrounding and distal uninfected parts of the plant, referred to as systemic acquired resistance (SAR) (Durrant and Dong 2004). These induced defense responses are regulated by a network of interconnected signal transduction pathways in which salicylic acid (SA) and jasmonic acid (JA) play key roles (Loake and Grant 2007; Spoel and Dong 2008; Truman et al. 2007).

In Arabidopsis, the NPR1 (nonexpressor of pathogenesisrelated genes 1) protein is a key regulator of SAR. NPR1 is essential for the activation of SA signaling and leads to enhanced expression of genes involved in basal resistance, such

Gerardo Sánchez and Nadia Gerhardt contributed equally to this work.

Current address of Gerardo Sánchez: Instituto Nacional de Tecnología Agropecuaria (INTA), Estación Experimental Agropecuaria San Pedro, Ruta Nac 9 Km 170, 2930, San Pedro, Buenos Aires, Argentina.

Corresponding author: María Rosa Marano; E-mail: marano@ibr.gov.ar as pathogenesis-related $(P R)$ genes (Pieterse and Van Loon 2004; Wang et al. 2006) and those that increase callose deposition (Dong et al. 2008). The activation of NPR1 is controlled by SA-mediated redox changes in the cell (Fobert and Despres 2005).

Numerous studies have shown that elevated levels of reactive oxygen species (ROS), including hydrogen peroxide $\left(\mathrm{H}_{2} \mathrm{O}_{2}\right)$, superoxide, and hydroxyl radical, are important in initiation of HR (Gechev et al. 2006). ROS also lead to cell fortification and induction of defense gene expression within and surrounding the infected cells (Torres et al. 2006). Chloroplasts are emerging as an important source of ROS that control plant defense responses (Muhlenbock et al. 2008). To neutralize these potentially toxic compounds, ROS scavengers (enzymatic and nonenzymatic antioxidants) are activated, thereby creating a shift toward reducing conditions in the plant cell.

$\mathrm{SA}$ is thought to act with ROS in a positive feedback cycle, promoting HR programmed cell death, as demonstrated in Arabidopsis (Leon et al. 1995; Shirasu et al. 1997). However, studies in other plant-pathogen systems have shown that SAmediated signaling differs depending on plant species. In tomato, it has been reported that the function of several resistance $(R)$ genes against fungi and bacteria is SA independent (Brading et al. 2000; Li et al. 2002). Tomato has basal SA levels two- to fourfold higher than tobacco and Arabidopsis (Raskin et al. 1990). Rice, which contains the highest basal SA levels among plant species tested thus far, does not significantly accumulate SA in disease resistance, and SA-deficient transgenic rice triggered spontaneous lesion formation and $\mathrm{H}_{2} \mathrm{O}_{2}$ production. The mechanism by which rice develops inducible disease resistance remains unclear. It has been suggested that SA might act directly as a preformed antioxidant to scavenge ROS (Yang et al. 2004).

Potato is known to have high basal SA levels (40- to 100fold higher than tobacco and Arabidopsis (Coquoz et al. 1995; Yalpani et al. 1991), and the role of SA in potato's defense has been controversial. Experiments by $\mathrm{Yu}$ and associates (1997) suggest that the high basal level of SA in potato does not play a role in defense against Phytophthora infestans. Indeed, treatment with SA has even been shown to increase disease symptoms in susceptible cultivars (Yu et al. 1997). In contrast, Couquoz and associates (1995) postulate that there is correlation between the levels of SA and the degree of resistance against $P$. infestans, based on the observation that young leaves of healthy potato plants with enhanced levels of SA are less susceptible to $P$. infestans than older leaves. In addition, they found that potato cultivars with nonspecific resistance against 
$P$. infestans contain higher levels of SA than susceptible ones. Interestingly, potato cultivars with high levels of SA exhibit constitutive expression of $P R$ genes (Navarre and Mayo 2004; Vleeshouwers et al. 2000). Recently, a steep increase in pathogen growth was demonstrated in potato plants depleted of SA (Halim et al. 2007). This increased susceptibility of NahG plants correlated with compromised callose formation and reduced early defense gene expression, suggesting that, as in other plants, potato also requires SA for basal defense.

To gain deeper insight into the contribution of SA to resistance responses in potato, we chose the well-characterized interaction between Potato virus $X(\mathrm{PVX})$ and the $\mathrm{Nb}$ resistance gene. $N b$ is a single dominant gene from cv. Pentland Ivory that confers HR to PVX strains ROTH1 and CP2, both of which carry the 25-kDa effector protein (Malcuit et al. 1999). To determine whether SA is required for $N b$-mediated resistance, we constructed SA-deficient transgenic potato plant cv. Pentland Ivory by overexpressing the salicylate hydroxylase gene (NahG) of Pseudomona putida. Using a combination of molecular, biochemical, genetic, and pathological analyses, we have studied the role of SA in this potato cultivar. In addition, we developed an Agrobacterium-mediated expression assay of the PVX $25 \mathrm{~K}$ gene to study the $N b$-dependent HR. Applying this system in combination with viral infection assays, we showed that SA is involved in Solanum tuberosum $\mathrm{Nb}$-mediated resistance.

\section{RESULTS}

\section{Expression of the NahG gene prevents SA accumulation in potato plants.}

To determine the role of SA in potato plants and to analyze its function in $\mathrm{Nb}$-mediated resistance, the $\mathrm{NahG}$ gene was introduced into potato cultivar, Pentland Ivory (genotype $N b$ ), under the control of the $35 \mathrm{~S}$ promoter via Agrobacterium-mediated transformation (Fig. 1A). We obtained four independently transformed potato $N a h G$ lines. The presence of the $N a h G$ gene on all regenerated potato plants was verified by polymerase chain reaction (PCR) and Southern blot (data not shown). Northern blot analysis indicated that plants from all lines accumulated similar NahG mRNA levels (Fig. 1A).

Nontransformed (Nt) and empty vector-transformed plants were used as controls. Free and total SA concentrations in the young leaves of $N a h G$ and control plants were measured by high-performance liquid chromatography (HPLC). Trace levels $(<0.05 \mu \mathrm{g}$ per gram of fresh weight) of free SA were found in control plants and each of the NahG lines. Most endogenous $\mathrm{SA}$ in cv. Pentland Ivory plants remained conjugated. In $\mathrm{NahG}$ plants, conjugated SA levels were greatly reduced to $0.061 \mu \mathrm{g}$ per gram of fresh weight, which is about 20 to 40 times below the total basal SA levels (approximately $1.7 \mu \mathrm{g}$ per gram of fresh weight) in Nt or vector-transformed cv. Pentland Ivory plants (Fig. 1B).

\section{Endogenous SA protects potato plants from oxidative stress.}

The phenotype of NahG plants is similar to that of control plants at early growth stages; however, after 7 to 8 weeks of development, necrotic lesions appeared spontaneously and expanded concentrically on the older leaves of all transgenic lines (Fig. 2A). To determine if the necrotic lesions are a consequence of abiotic oxidative stress in the SA-deficient plant, 2-week-old $N a h G$ plants were submitted to high light conditions $(620 \mu \mathrm{E}$ $\left.\mathrm{m}^{-2} \mathrm{~s}^{-1}\right)$. After 21 days of light exposure, $40 \%$ of the $N a h G$ plants (four of ten) developed necrotic lesions. The remaining six plants developed necrotic lesions after reaching advanced growth stages. Neither Nt nor empty vector-transformed plants developed lesions during light exposure (data not shown).
High light intensity has been shown to promote oxidative stress (Bray et al. 2000), and the necrotic lesions observed on $N a h G$ plants could result from this type of stress. Based on this observation, we decided to analyze the plant response to other conditions that promote oxidative stress. NahG and control plants were exposed to the herbicide methyl viologen (MV), which is an active redox compound that induces oxidative stress by stimulating the production of ROS, primarily at the chloroplast level (Asada 1996). The ROS overproduced in response to MV leads to cellular membrane damage and electrolyte leakage through lipid peroxidation (Laloi et al. 2004; Lam 2004).

Potato leaf disks selected at random were subjected to different concentrations of $\mathrm{MV}(0,5,10,20,40$, and $100 \mu \mathrm{M})$ followed by $2,7,9,12,18$, and $36 \mathrm{~h}$ of light exposure $(270 \mu \mathrm{E}$ $\left.\mathrm{m}^{-2} \mathrm{~s}^{-1}\right)$, after which $\mathrm{MV}$-induced damage was immediately measured.

The percentage of electrolyte leakage differed significantly between $N a h G$ and control plants after $12 \mathrm{~h}$ of light exposure, indicating more membrane damage in $N a h G$ plants (Fig. 2B). Similar results were obtained following $18 \mathrm{~h}$ of light exposure. Differences in conductivity were not significant for light exposure durations shorter than $12 \mathrm{~h}$. These results indicate that $N a h G$ potato plants were more sensitive to MV-induced oxidative stress than were control plants. At high concentrations of MV, NahG leaf disks exhibited more severe photobleaching than did control plants, indicating further oxidative damage (Fig. 2C). There were no significant differences in the level of response to these abiotic stresses among individual lines carrying this transgene (data not shown).

SA deficient $N a h G$ leaves contain higher levels of $\mathrm{H}_{2} \mathrm{O}_{2}$.

We analyzed ROS production levels in $N a h G$ and $\mathrm{Nt}$ plants at distinct stages of development to gain better understanding

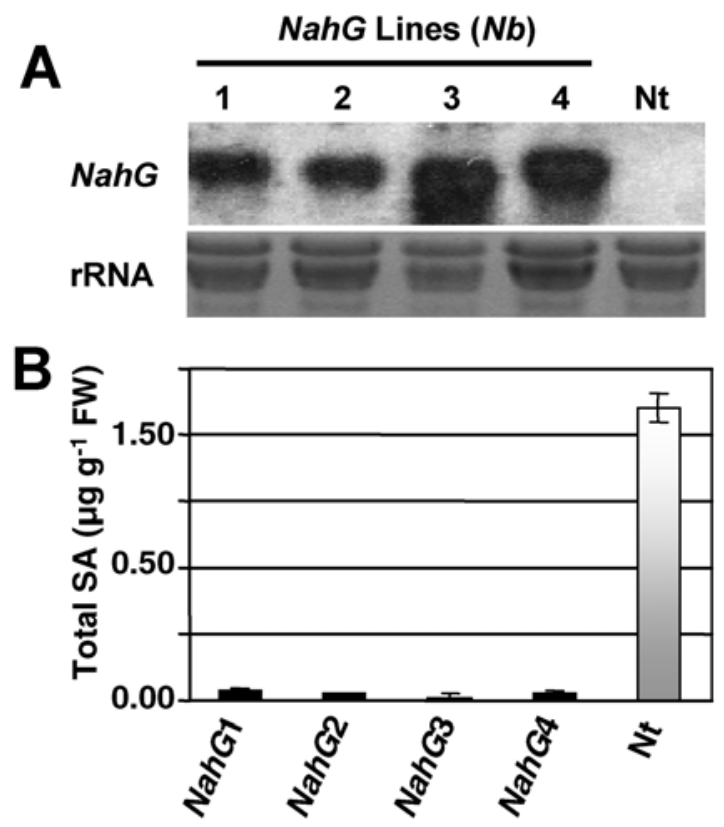

Fig. 1. Constitutive expression of the $N a h G$ gene and corresponding salicylic acid (SA) levels in transgenic potato cv. Pentland Ivory. A, Total RNA was isolated from the leaf tissue of four independent $N a h G(N b)$ lines and from nontransformed (Nt) $N b$ plants and was hybridized with $\alpha$ ${ }^{32}$ P-labeled $N a h G$ DNA probe. Equal loading was monitored by ethidium bromide staining of total RNA. B, Leaf disks of four-week-old plants were analyzed for total SA and free SA concentrations in NahG and Nt plants. Each column represents the mean value of total SA \pm standard deviation of three replicates, each consisting of leaves from four plants per transgenic line. Empty vector-transformed plants were also used as controls with the same result as $\mathrm{Nt}(\mathrm{Nb})$ plants. 
to the cellular redox balance that makes SA deficient plants more susceptible to oxidative stress. The production or accumulation of subcellular $\mathrm{H}_{2} \mathrm{O}_{2}$ was examined microscopically after staining with 3,3'-diaminobenzidine (DAB) (ThordalChristensen et al. 1997) and with fluorescence marker 2',7'-dichlorofluorescein diacetate (DCFH-DA), respectively (Ezaki et al. 2000).

After 7 to 8 weeks of plant development, a spectrum of leaves were taken from control and $N a h G$ plants and analyzed

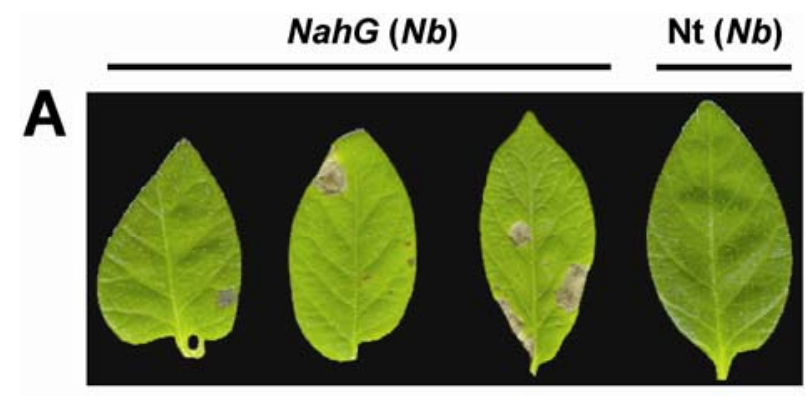

B
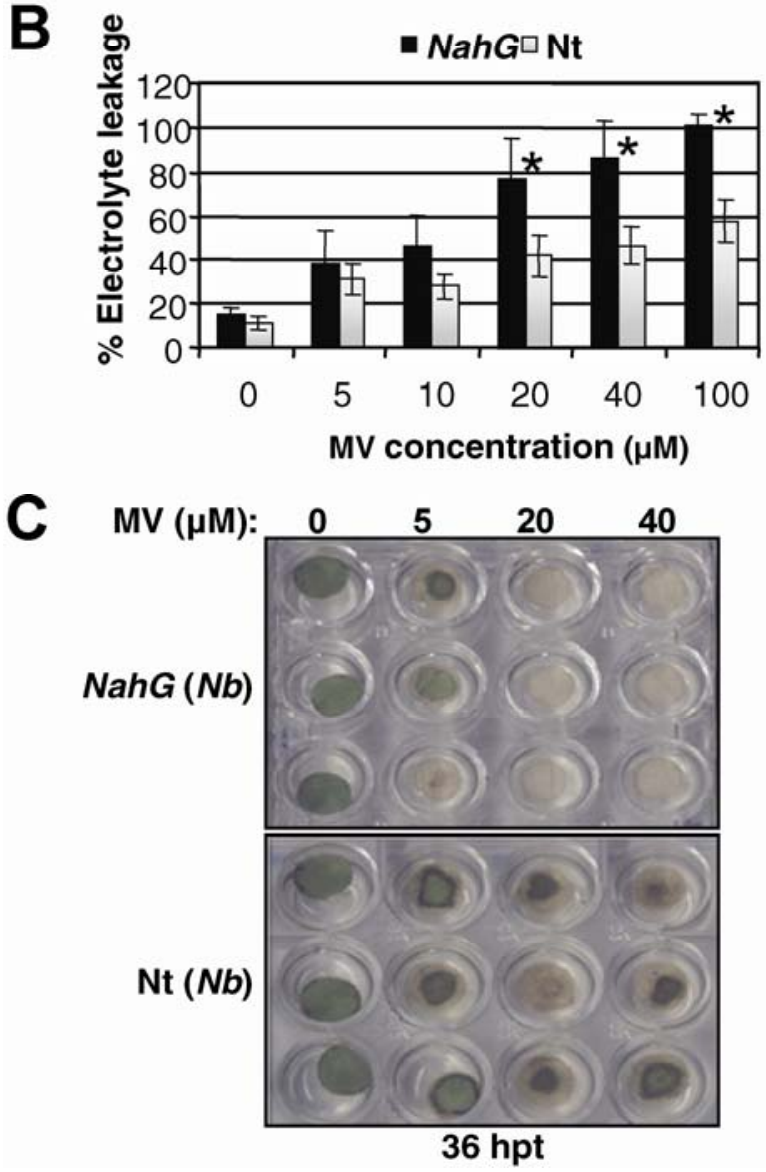

Fig. 2. Response of $N a h G$ plants to abiotic stress. A, Plants at similar growth stages ( 7 to 8 weeks) were grown under 150 to $200 \mu \mathrm{E} \mathrm{m}^{-2} \mathrm{~s}^{-1}$ light intensity over a 16-h photoperiod. The spontaneous lesion formations are representative of the four transgenic $N a h G$ plants. B, Response of $N a h G$ plants to the oxidative damage caused by treatment of methyl viologen (MV). Leaf disks of NahG line 4 and nontransformed (Nt) plants were treated with different concentrations of $\mathrm{MV}(0,5,10,20,40$, or $100 \mu \mathrm{M})$. Values are mean \pm standard deviation of six independent leaves for each concentration at $12 \mathrm{~h}$ after treatment. The set marked with an asterisk is significantly different as assessed by one-way analysis of variance: $* P<$ 0.05 . C, Effects of MV on leaf bleaching of NahG line 4 and Nt potato plants at $36 \mathrm{~h}$ posttreatment (hpt) with $0,5,20$, or $40 \mu \mathrm{M}$ MV. Similar results were obtained with $N a h G$ lines 1 through 3, with two independent experiments conducted for each line. Empty vector-transformed plants were also used as controls with the same result as with $\mathrm{Nt}(\mathrm{Nb})$ plants. for $\mathrm{H}_{2} \mathrm{O}_{2}$ levels. As indicated by the stronger reddish-brown coloration and DCF-dependent green fluorescent signals in Figure $3 \mathrm{~A}$ and B, respectively. Older leaves (the tenth leaf below the youngest leaf) of SA-deficient $N a h G$ plants accumulate significantly higher levels of peroxides than Nt leaves under normal growth conditions controlled for temperature, light, and humidity. Subtle differences in peroxide levels were observed between younger leaves of NahG and Nt plants (data not shown). Similar staining seen in older leaves was observed in control leaves treated with $\mathrm{H}_{2} \mathrm{O}_{2}$ (data not shown).

\section{Antioxidant capacity in potato leaves.}

We have shown that $N a h G \mathrm{cv}$. Pentland Ivory plants contain high levels of $\mathrm{H}_{2} \mathrm{O}_{2}$ and are more sensitive to stress conditions. These results could indicate that $N a h G$ plants have a decreased capacity to detoxify ROS with respect to control plants. The high levels of ROS in NahG potato plants might indicate that either SA has an antioxidant effect in cv. Pentland Ivory or that catechol, the product of SA degradation by $N a h G$, has pro-oxidative effects.

Catechol-mediated $\mathrm{H}_{2} \mathrm{O}_{2}$ production has been hypothesized to play a role in the loss of resistance of NahG Arabidopsis plants to pathogens (van Wees and Glazebrook 2003). To analyze the status of the antioxidant defense system in SA-deficient potato, we measured the radical-scavenging activity (RSA) of flavonoids and phenolic (nonenzymatic) antioxidant compounds from young and old potato leaf extracts against the

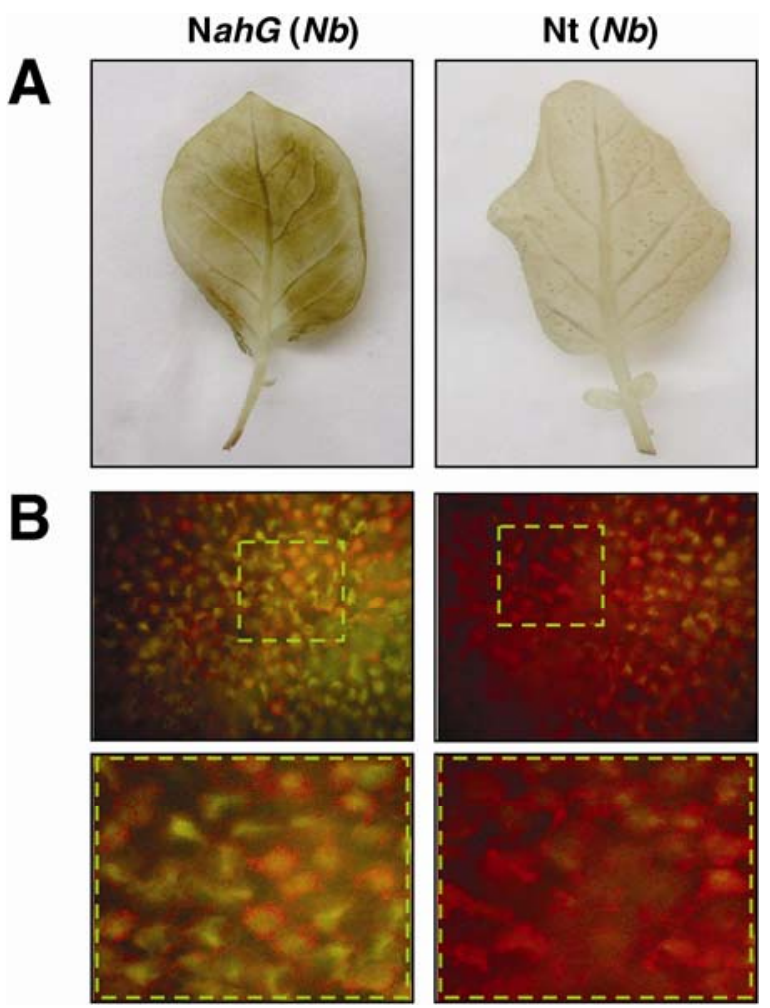

Fig. 3. Comparison of $\mathrm{H}_{2} \mathrm{O}_{2}$ production between $N a h G$ and nontransformed $(\mathrm{Nt})$ potato plants. Older leaves from 7-week-old potato plants

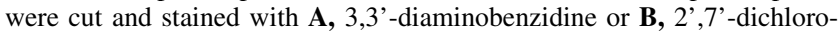
fluorescein diacetate. Sections from the upper panels are shown magnified in the lower panels. Red indicates chlorophyll autofluorescence. Leaves were photographed under white and UV light $(520 \mathrm{~nm})$, respectively. Three independent biological assays were carried out for each of the four transgenic $N a h G$ lines, using 10 of the youngest leaves (L1) and 10 older leaves (the tenth leaf below the youngest leaf, L10) from 10 to $15 \mathrm{NahG}$ $\mathrm{Nb}$ ) plants and 10 to $15 \mathrm{Nt}(\mathrm{Nb})$ plants for the control. Empty vectortransformed plants were also used as controls with the same result as $\mathrm{Nt}$ $(\mathrm{Nb})$ plants. 
free radicals 2,2'-azinobis (3-ethylbenzothiazoline-6-sulfonic acid) (ABTS) and 1,1-diphenyl-2-picrylhydrazyl (DPPH) (Gülçin et al. 2007) (Pellegrini et al. 1999). The ABTS (Fig. 4A) and DPPH (data not shown) assays revealed no difference in RSA between NahG and control leaves. However, in concordance with our previous results, younger leaves displayed higher levels of RSA than older leaves across both NahG and control plants.

Using ABTS as a basis, we then compared the RSA of SA and catechol (both pure grade). Our results indicate that catechol has strong RSA and confirm the weak RSA of SA itself, as was shown previously (Sroka and Cisowski 2003) (data not shown). These findings suggest that SA does not contribute to the antioxidant capacity of control plants and that catechol does, though this activity is absent in NahG plants.

To further confirm this hypothesis and to look for possible changes in the antioxidant composition responsible for RSA, we analyzed the composition of methanolic extract, using thin-layer chromatography (TLC), and the corresponding RSA activity, using ABTS and DPPH assays. As shown in Figure 4B, NahG and control plants show a similar pattern of antioxidant compounds, suggesting that the nonenzymatic antioxidant system is not compromised by NahG expression. However, the total concentration of RSA was significantly greater in younger leaves compared with older leaves (Fig. 4B). TLC analysis did not detect free SA on control leaf extracts or catechol-derived antiradical activity on $N a h G$ leaf extracts, confirming that these compounds do not significantly contribute to overall RSA (Fig. 4B). We confirmed the free catechol measurement by gas chromatography coupled to mass spectrometry (GC-MS), which is more specific than TLC and more sensitive than HPLC (Brading et al. 2000; Yang et al. 2004). Through GC-MS, we detected low amounts of free catechol in Nt (approximately $0.24 \mu \mathrm{g}$ per gram of fresh weight) and $N a h G$ leaves (approximately $0.3 \mu \mathrm{g}$ per
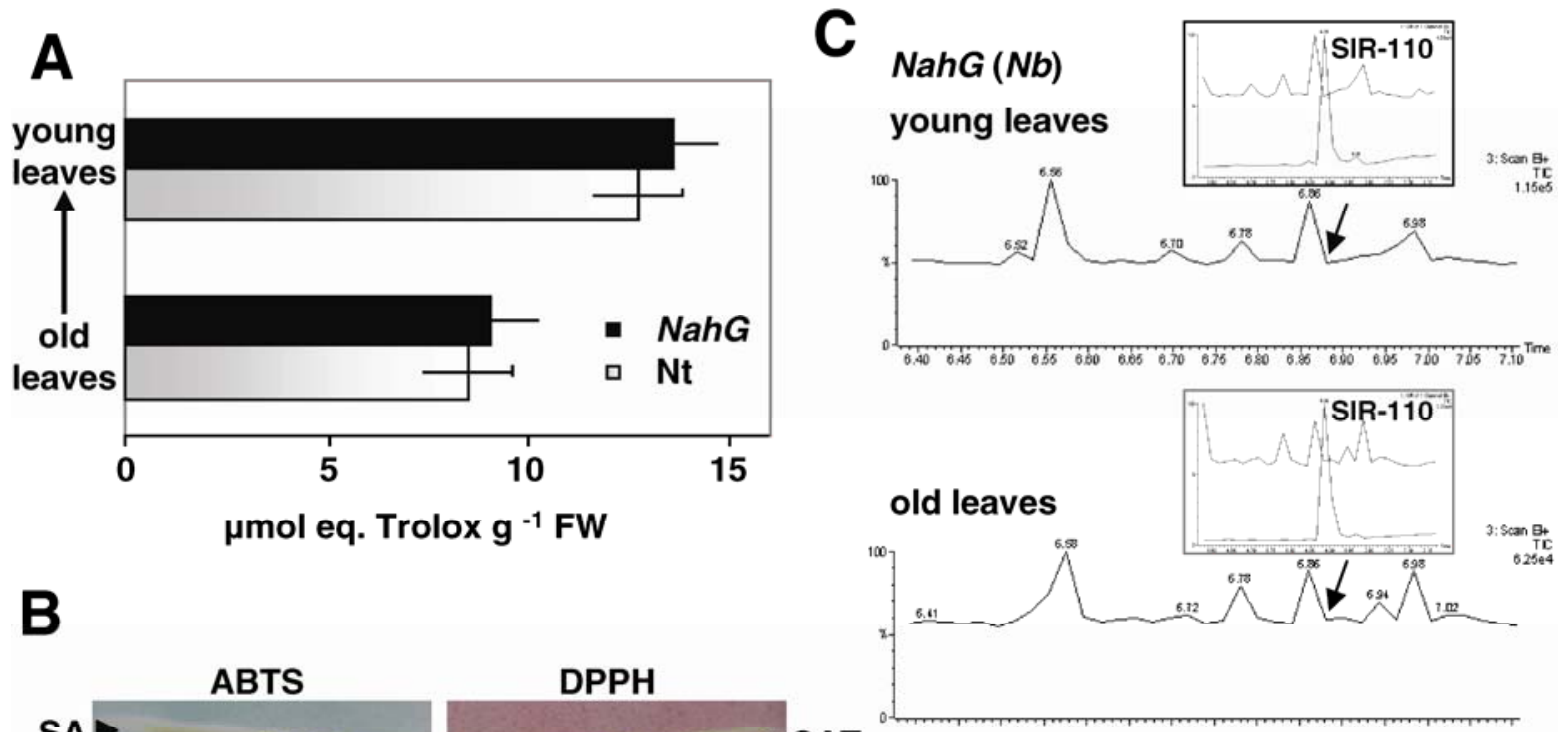

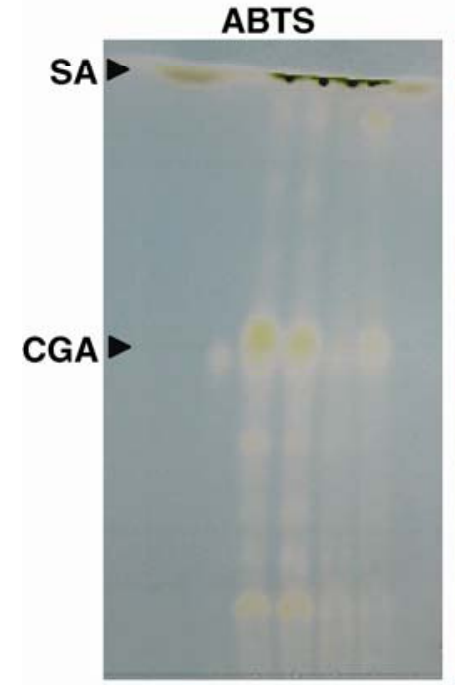

12345667

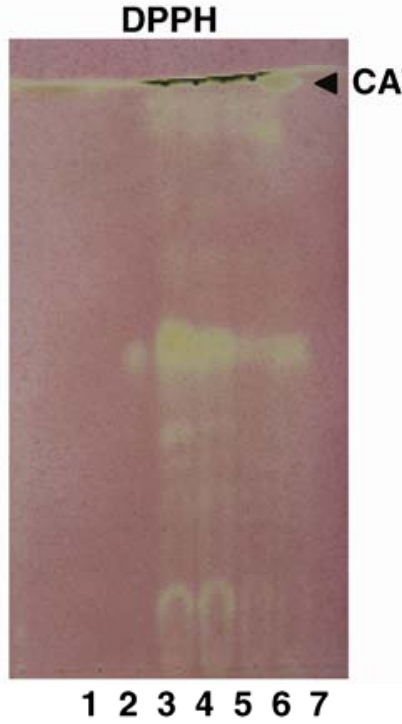

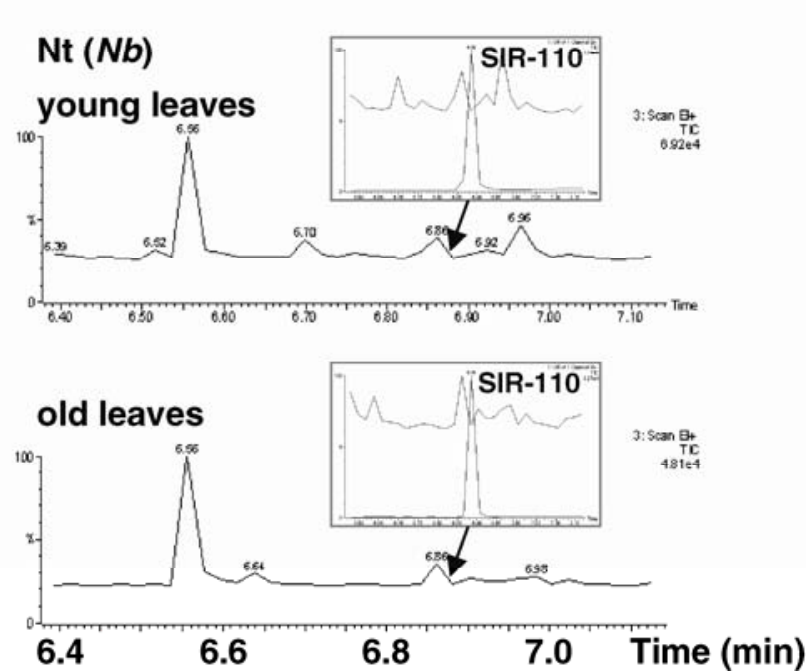

Fig. 4. Antioxidant capacity of $N a h G$ and control potato cv. Pentland Ivory. Young and old potato leaves of $N a h G$ and nontransformed (Nt) plants at similar growth stages ( 7 to 8 weeks old) were analyzed. A, Levels of total antioxidant activity in methanolic extracts of potato leaves, as determined by 2,2 '-azinobis (3-ethylbenzothiazoline-6-sulfonic acid) (ABTS). Radical scavenging capacity was expressed as 2-hydroxy-2,5,7,8-tetramethylchroman-2-carboxilic acid (Trolox) equivalents per gram of fresh weight tissue ( $\mu$ mol eq. Trolox $\mathrm{g}^{-1} \mathrm{FW}$ ) Data shown represent means \pm standard deviation of three independent experiments. B, Thin-layer chromatograms, visualized by ABTS or DPPH reagents, of methanolic extracts from young (3, 4) and old (5, 6) potato leaves of Nt and $N a h G$ plants, respectively. Standards: salicylic acid (1), chlorogenic acid (2), catechol (7). C, Gas chromatography-mass spectrometry chromatographs of the methanol fraction from NahG and Nt potato plants. In all cases diacetyl catechol derivates were analyzed based on the selected ion recording (SIR)-110, with a retention time of $6.89 \mathrm{~min}$, as indicated by the arrow. Only a part of chromatogram is shown. The boxed inset shows the magnified retention time with the overlapping of peak of the reference compound diacetyl catechol. A minimum of 10 leaves from 10 to 15 plants per genotype ( $N a h G$ line 4 and Nt $N b$ plants) were analyzed with highly similar results. Empty vector-transformed plants were also used as controls with the same result as Nt ( $\mathrm{Nb}$ ) plants. 
gram of fresh weight) and did not observe differences between young and old leaves in either NahG or Nt plants (Fig. 4C). Taken together, these results suggest that the different responses of $N a h G$ and control plants to oxidative stress are due to the function of SA as a molecular signal rather than the chemical properties of SA or catechol.

Role of $\mathrm{SA}$ in $\mathbf{N b}$-mediated defense response in potato.

To determine the role of SA in $N b$-mediated HR, $N a h G(N b)$, nontransgenic resistant $(N b)$, and susceptible $(n b)$ potato plants were inoculated with PVX ROTH1 and the $N b$ resistancebreaking strain UK3 (Malcuit et al. 1999). NahG and nontrans- genic $N b$ leaves developed HR lesions 3 days after inoculation with the avirulent virus strain ROTH1. HR lesions on NahG were significantly larger and more numerous than those of nontransgenic $\mathrm{Nb}$ plants, and no hypersensitive lesions were observed on $n b$ potato plants (Fig. 5A). On the other hand, HR lesions on $N a h G$ leaves were able to spread through secondary veins. Lesions never spread to primary veins. NahG younger leaves developed no symptoms, indicating the virus had not spread systemically despite increased HR lesions on inoculated leaves.

Following inoculation with virulent strain UK3, NahG, nontransgenic $N b$, and $n b$ leaves developed no HR lesions and
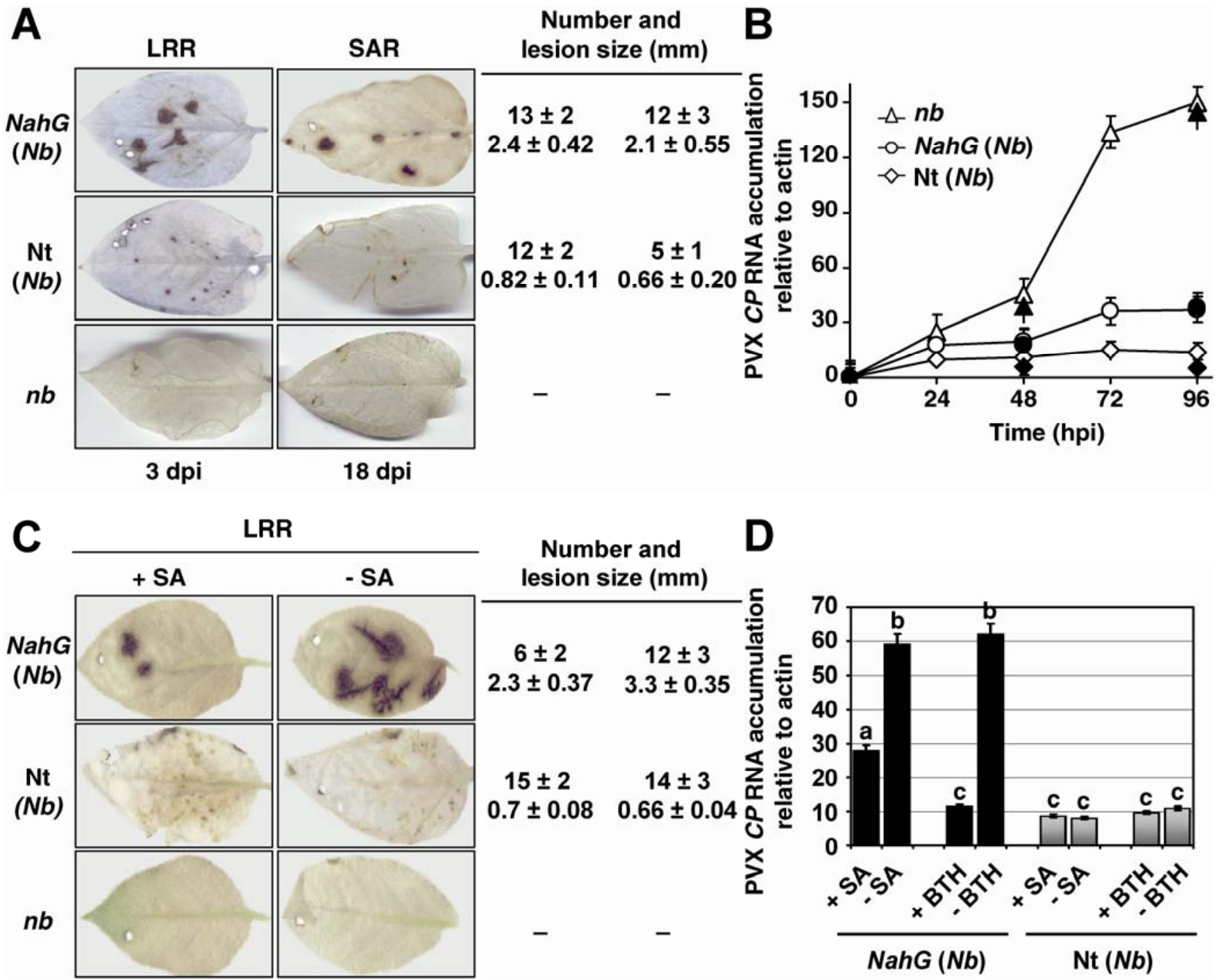

Fig. 5. Effect of salicylic acid (SA) on the $N b$-mediated hypersensitive response (HR). Pentland Ivory resistant (NahG line 4 and control) and susceptible $(n b)$ leaves were mechanically inoculated with Potato virus X (PVX) ROTH1. A, Leaves were cut at 3 days postinoculation and were bleached with ethanol to observe the HR (black spots) more clearly. The local resistance response (LRR) was induced on inoculated $\mathrm{Nb}$ leaves; the systemic acquired resistance (SAR) was induced on systemic $N b$ potato leaves 3 days after the second inoculation of uninfected systemic leaves with PVX ROTH1. B, Quantitative reverse transcription-polymerase chain reaction (qRT-PCR) analysis of PVX coat protein $(C P)$ gene accumulation after the first and second infection in PVX ROTH1-infected $N a h G(N b)$, nontransformed $(\mathrm{Nt})(\mathrm{Nb})$, and susceptible $(n b)$ potato leaves relative to actin. Average cycle threshold values and $n$-fold changes in gene expression in each infection experiment compared with those of the reference sample were calculated from triplicate experiments. Error bars indicate standard deviations from two independent experiments. The white and black symbols indicate the levels of virus accumulation during the first (LRR) and second (SAR) infection with PVX, respectively. C, Effect of PVX ROTH1 infection in potato leaves treated with $5 \mathrm{mM} \mathrm{SA}(+\mathrm{SA})$ or with $15 \mathrm{mM}$ $\mathrm{Na}_{2} \mathrm{HPO}_{4}(-\mathrm{SA})$. The number and size of lesions shown in panels $\mathrm{A}$ and $\mathrm{C}$ were measured (in $\mathrm{mm} \pm$ standard deviation) at 3 days after $1^{\circ}(\mathrm{LRR})$ and $2^{\circ}$ (SAR) PVX ROTH1 infection and after application of $5 \mathrm{mM} \mathrm{SA}$, using the program ImageJ software v1.41 (National Institute of Health, Bethesda, MD, U.S.A.). The experiment was performed three times, using a minimum of four leaves per plant. $\mathbf{D}, N a h G(N b)$, and $\mathrm{Nt}(\mathrm{Nb})$ potato leaves were treated with either $0.5 \mathrm{mM}$ SA or $0.5 \mathrm{mM}$ benzo(1,2,3)-thiadiazole-7-carbothioic acid $S$-methyl ester (BTH) $24 \mathrm{~h}$ prior to infection with PVX ROTH1. qRT-PCR analysis of PVX CP RNA was measured 2 days after infection as described in B. Control plants (treated with either $15 \mathrm{mM} \mathrm{Na}_{2} \mathrm{HPO}_{4}$ or a solution containing no active BTH) were also inoculated and analyzed for virus accumulation. Error bars indicate standard deviations from three independent experiments. Data sets marked with different letters are significantly different as assessed by one-way analysis of variance: $P<0.05$. Similar results were obtained with the NahG lines 1, 2, and 3. Empty vector-transformed plants were also used as controls with the same result as $\mathrm{Nt}(\mathrm{Nb})$ plants. 
showed characteristic mosaic symptoms of PVX on systemic leaves (data not shown).

Analysis of SA through GC-MS shows free SA in $\mathrm{Nt}(\mathrm{Nb})$ potato leaves 2 days postinfection with PVX- ROTH1 increased to $5.56 \mu \mathrm{g}$ per gram of fresh weight, which represents a 100 fold induction in response to virus infection, although this increase was not observed in susceptible $(n b)$ or $N a h G(N b)$ plants after virus infection.

To determine whether SA is involved in SAR induction mediated by the $N b$ gene in potato, we analyzed distal leaves of $N a h G$ and Nt $N b$ and $n b$ plants inoculated with PVX ROTH1 virions. At 15 days after inoculation, systemic leaves from the same plant were inoculated for the second time with PVX ROTH1. Figure 5A shows the phenotype of leaves 3 days after the second inoculation with ROTH1. The lesion diameter on $N a h G$ plants was similar after first and second inoculations. In $\mathrm{Nt} \mathrm{Nb}$ plants, fewer lesions were generated after the second inoculation compared with the first inoculation, though the same concentration of inoculum was used. These data indicate that $\mathrm{SA}$ is involved in the $N b$-mediated local and systemic defense response.

To confirm that number and size of HR lesions positively correlates with virus accumulation, we measured the spread of PVX ROTH1 by quantitative reverse transcription (qRT)-PCR of PVX coat protein $(C P)$ RNA over a 4-day period $(0,24,48$, 72 , and $96 \mathrm{~h}$ ) after PVX infection in $\mathrm{Nt}(\mathrm{Nb}), N a h G(\mathrm{Nb})$, and susceptible $(n b)$ potato plants. As shown in Figure $5 \mathrm{~B}$, the levels of PVX ROTH1 $C P$ RNA rose more rapidly in $N a h G(N b)$ plants than in $\mathrm{Nt}(\mathrm{Nb})$, such that, $96 \mathrm{~h}$ after inoculation, the amount of accumulated PVX $C P$ RNA was about 2.5-fold greater in $N a h G(N b)$ plants than in $\mathrm{Nt}(\mathrm{Nb})$ plants. These results correlate the reduction in HR lesion size and number with the observed restriction of virus replication and cell-to-cell spread on local leaves. Virus accumulation on distal leaves was analyzed 0,48 , and $96 \mathrm{~h}$ after a second PVX infection in $\mathrm{Nt}$ $(\mathrm{Nb}), N a h G(\mathrm{Nb})$, and susceptible $(n b)$ potato plants previously infected with PVX ROTH1 (using plants whose leaves had not been detached for analysis of the first infection). In Nt potato plants, the levels of PVX CP RNA in the distal infected leaves was 2.6- to 3-fold lower compared with levels in the first-time virus-inoculated leaves (Fig. 5B). NahG ( $\mathrm{Nb}$ ) plants, by comparison, showed no significant differences in PVX $C P$ RNA accumulation on distal leaves receiving a second PVX ROTH1 infection compared with first-time inoculated leaves (Fig. 5B). Viral replication in the distal PVX-infected leaves of Nt potato plants mock-inoculated in the primary infection was similar to viral replication observed in first-time virus-inoculated leaves (data not shown). Considerable PVX CP RNA accumulation was detected in susceptible $(n b)$ plants and no difference in virus accumulation was observed between the leaves inoculated during the first and second rounds of infections (Fig. 5B). Together, these results strongly suggested that $\mathrm{SA}$ is required for $\mathrm{Nb}$-mediated resistance to PVX.

To support the theory that SA levels and defense responses downstream of SA play a role in potato resistance to PVX infection, the abaxial side of $\mathrm{Nt}(\mathrm{Nb}$ and $n b)$ and $N a h G$ potato plants were sprayed with $5 \mathrm{mM} \mathrm{SA}$ solution $24 \mathrm{~h}$ prior to inoculation with PVX ROTH1 (Fig. 5C). As a treatment control, $\mathrm{Nt}$ and $N a h G$ potato leaves were sprayed with $15 \mathrm{mM}$ $\mathrm{Na}_{2} \mathrm{HPO}_{4}$, pH 6.5. SA-treated $N a h G$ plants exhibited fewer and smaller HR lesions $48 \mathrm{~h}$ postinoculation, demonstrating that $\mathrm{SA}$ is involved in the number and diameter of the lesion and, consequently, resistance to PVX (Fig. 5C). In addition, SA treatment also decreased the spread of HR in NahG plants, though not to the same extent as observed in nontransgenic $(\mathrm{Nb})$ plants. In contrast SA treatment did not significantly alter number or lesion size in nontransgenic $N b$ plants (Fig. 5C).
qRT-PCR of PVX ROTH1 $C P$ RNA by $48 \mathrm{~h}$ after PVX infection in $N a h G(N b)$ and $\mathrm{Nt}(\mathrm{Nb})$ potato plants confirmed these findings (Fig. 5D). Although SA application does not completely restore the $N b$-mediated resistance to $N a h G(N b)$ plants, the difference in PVX ROTH1 $C P$ RNA accumulation in SA-treated $N a h G(N b)$ plants was reduced by $50 \%$ when compared with $N a h G(\mathrm{Nb})$ plants not treated with SA (Fig. 5C and D). The most likely explanation for the partial rescue of the phenotype in the $N a h G$ plants is that exogenous SA is either being partially metabolized to catechol or its concentration is not great enough to reach the threshold levels of endogenous SA of the Pentland Ivory cultivar. To distinguish these possibilities, NahG plants were treated with the SA analog benzo(1,2,3)-thiadiazole-7-carbothioic acid $S$-methyl ester (BTH) (Schurter et al. 1987). NahG $(\mathrm{Nb})$ and $\mathrm{Nt}(\mathrm{Nb})$ potato leaves were sprayed with $5 \mathrm{mM}$ BTH $24 \mathrm{~h}$ prior to PVX ROTH1 inoculation. As a treatment control, Nt and NahG potato leaves were sprayed with a carrier powder solution containing no active BTH $(0 \mathrm{mM})$. At $48 \mathrm{~h}$ postinoculation with PVX, we observed a significant restriction in the number and size of lesions on $N a h G$ plants pretreated with BTH as compared with $N a h G$ plants treated with the carrier power solution (data not shown). The HR lesions were similar in number and size to those observed on nontransgenic $\mathrm{Nb}$ plants pretreated with BTH (data not shown). To confirm that BTH rescues the SA-deficiency phenotype in the NahG plants, we measured the expression of PVX ROTH1 CP RNA. As shown in Figure 5D, $48 \mathrm{~h}$ after virus infection, PVX ROTH1 $C P$ RNA levels were reduced by $80 \%$ in NahG plants treated with BTH as compared with $N a h G$ control plants (treated with carrier powder solution), approximating the levels detected in $\mathrm{Nt}(\mathrm{Nb})$ plants inoculated with the virus. Here, too, we found that nontransgenic resistant Pentland Ivory plants treated with BTH show no difference in virus accumulation compared with plants without treatment (Fig. 5D). These results support the conclusion that the loss of SA accumulation in $N a h G(N b)$ plants is responsible for the increased susceptibility to PVX.

Although, no differences in free catechol levels were observed between $N a h G$ and Nt potato plants, we wished to determine if catechol could be responsible for the enhanced susceptibility to PVX ROTH1 in NahG $(\mathrm{Nb})$ potato plants. To address this, nontransgenic $(\mathrm{Nb})$ plants were sprayed with either $1 \mathrm{mM}$ catechol or $10 \mathrm{mM} \mathrm{MgCl} 24 \mathrm{~h}$ prior to infection with PVX ROTH1. The HR lesions induced by the $N b$-mediated resistance response were quantified 3 days postinfection. No significant differences in number or size were found (data not shown). These results confirm that catechol itself does not enhance susceptibility to PVX ROTH1 in NahG $(\mathrm{Nb})$ potato plants.

\section{Agrobacterium-based transient expression of the PVX 25-kDa protein elicits $N b$-mediated HR.}

Previously, we demonstrated that the expression of the PVX ROTH1 25-kDa protein by particle bombardment in potato leaves elicits $N b$-mediated HR (Malcuit et al. 1999). However, as with viral inoculation, it is not easy in this system to predict the sites of lesion formation before HR elicitation. Consequently, we developed an agroinfiltration-mediated assay to express PVX $25-\mathrm{kDa}$ protein in potato leaves. Genes coding for PVX avirulent (25K1) and virulent (25K3) $25-\mathrm{kDa}$ protein were cloned under the control of two $35 \mathrm{~S}$ minimal promoters into pBIN19 binary vectors to produce $\mathrm{pBIN} 25 \mathrm{~K} 1$ and pBIN25K3, respectively.

$N a h G$, nontransgenic resistant $(N b)$, and susceptible $(n b)$ leaves were infiltrated with Agrobacterium containing pBIN25K1 and pBIN25K3, respectively, and ROS levels, callose deposition, and $P R$ gene expression were analyzed at dif- 
ferent times postinfiltration to investigate the SA effect on the $\mathrm{Nb}$-dependent defense induction.

$N a h G(N b)$ and nontransgenic $N b$ leaves infiltrated with Agrobacterium culture harboring pBIN25K1 plasmid developed HR within the infiltrated area $48 \mathrm{~h}$ postinoculation (Fig. 6A). However, SA-deficient transgenic plants exhibited earlier HR lesions, extending beyond the area of infiltration. Susceptible $(n b)$ leaves developed no necrosis within $72 \mathrm{~h}$ postinoculation (Fig. 6A). $N a h G(\mathrm{Nb})$ and nontransgenic $N b$ leaves infiltrated with pBIN25K3-transformed Agrobacterium cultures, empty vector-transformed Agrobacterium cultures, or $10 \mathrm{mM} \mathrm{MgCl}$ developed no necrosis. The production of $\mathrm{H}_{2} \mathrm{O}_{2}$ was detected indirectly through DAB staining (Thordal-Christensen et al. 1997), at $16 \mathrm{~h}$ postinfiltration in nontransgenic $\mathrm{Nb}$ leaves infiltrated with pBIN25K1 (Fig. 6B). Leaves of SA-deficient $N a h G$ plants accumulate slightly higher levels of $\mathrm{H}_{2} \mathrm{O}_{2}$ than $\mathrm{Nt}$ plants. Interestingly, the presence of $\mathrm{H}_{2} \mathrm{O}_{2}$ was also observed in SA-deficient $N a h G(\mathrm{Nb})$ plants agroinfiltrated with pBIN25K3 (Fig. 6B). The presence of $\mathrm{H}_{2} \mathrm{O}_{2}$ is characteristic of plant tissues undergoing HR (Fobert and Despres 2005). Only $N a h G(N b)$ plants showed $\mathrm{H}_{2} \mathrm{O}_{2}$ during compatible interaction, confirming inappropriate production of $\mathrm{H}_{2} \mathrm{O}_{2}$ in this transgenic potato cultivar. The assay is negative for both susceptible $(n b)$ leaves infiltrated with pBIN25K1 (Fig. 6B) and resistant $(\mathrm{Nb})$ leaves infiltrated with pBIN25K3 (Fig. 6B). Callose deposition was visible in $\mathrm{Nt} N b$ plants inoculated with pBIN25K1, as indicated by the bright-light blue stain (Fig. 6C). NahG (Nb) leaves showed no callose deposition $16 \mathrm{~h}$ after $\mathrm{Nb}$ elicitation. As expected, no callose deposition was observed on susceptible $(n b)$ leaves inoculated with pBIN25K1 (Fig. 6C) or on $N a h G$ $(\mathrm{Nb})$ and $\mathrm{Nt}(\mathrm{Nb})$ leaves infiltrated with pBIN25K3 (Fig. 6C).

To analyze the expression of $P R-1 a$ by Northern blot, samples of the infiltrated areas were taken at different time points. $P R-1 a$ expression in $N a h G$ and resistant $(N b)$ peaked $20 \mathrm{~h}$ postinoculation (Fig. 6D). Even though the induction of $P R-1 a$ in $N a h G$ and $N b$ plants do not differ significantly, at 6 h postinfiltration a weak signal was detected in $\mathrm{Nb}$ plants, which indicates that induction in these plants began earlier, while in $N a h G$ plants the expression levels remain high over a longer period (Fig. 6D). Susceptible $(n b)$ leaves showed no $P R-1 a$ expression after $25 \mathrm{~K} 1$ agroinfiltration (data not shown). These results demonstrated that Agrobacterium-based 25K1 expression induced the HR response in an $\mathrm{Nb}$-dependent manner and that $\mathrm{SA}$ is involved in the early defense response.

\section{DISCUSSION}

In this work, potato cv. Pentland Ivory carrying the $R$ gene $\mathrm{Nb}$, which confers hypersensitive resistance to PVX (Marano et al. 2002), was transformed with the $N a h G$ gene from Pseudomonas putida. The reduced levels of conjugated SA in $N a h G$ potato cv. Pentland Ivory (Fig. 1) induce the development of spontaneous necrotic lesions, stimulated by tissue aging and high light intensities (Fig. 2A). Although the necrotic pheno-

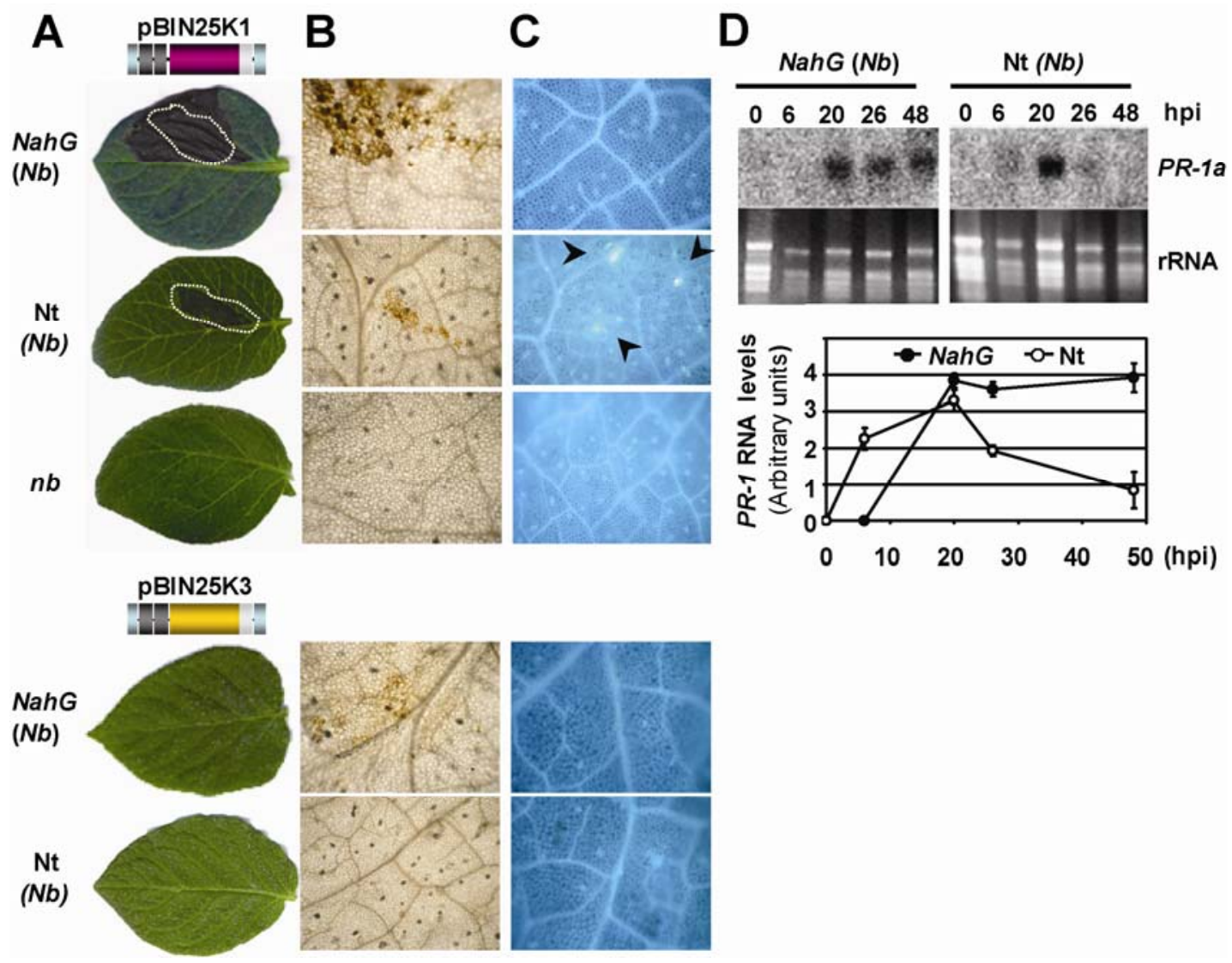

Fig. 6. $N b$-mediated hypersensitive response (HR) to the viral effector $25 \mathrm{~K} 1$. A, Pentland Ivory resistant ( $N a h G$ line 4 and nontransformed [Nt]) ( $N b)$ and susceptible $(n b)$ leaves were infiltrated with either pBIN25K1 or pBIN25K3, and tissue samples were harvested at indicated time points. The dotted yellow lines show the HR, manifested by the appearance of necrotic lesions within the agroinfiltrated area $48 \mathrm{~h}$ postinoculation. B, Potato leaves were stained with 3,3'-diaminobenzidine or $\mathbf{C}$, aniline blue at $16 \mathrm{~h}$ postinfiltration to detect $\mathrm{H}_{2} \mathrm{O}_{2}$ accumulation and callose deposition, respectively. Callose deposition is indicated by arrows (D) RNA was extracted from the infiltrated tissues at $0,6,20,26$, and $48 \mathrm{~h}$ postinoculation (hpi) and the transcript level of $P R$-1a was determined by RNA gel-blot analysis. Ethidium bromide staining of rRNA was used as a loading control. The induction of $P R$ - $1 a$ RNA levels relative to $25 \mathrm{~S}$ rRNA (arbitrary unit) was quantified by densitometry with the ImageJ software v1.41 (National Institutes of Health Bethesda, MD, U.S.A.). Similar results were obtained with two independent sets of RNA extracts. Empty vector-transformed plants were also used as controls with the same result as Nt $(\mathrm{Nb})$ plants. 
type was also observed in NahG tomato (Brading et al. 2000) and in NahG rice (Yang et al. 2004), it has not been observed in SA-deficient transgenic tobacco plants (Brading et al. 2000; Gaffney et al. 1993; Mur et al. 1997), nor has it been observed in NahG Arabidopsis plants (Delaney et al. 1994).

The necrosis phenotype is associated with an increase of $\mathrm{H}_{2} \mathrm{O}_{2}$ accumulation in NahG potato leaves (Fig. 3). ROS-dependent cell death in this potato cultivar confirms previous hypotheses that high endogenous levels of SA protect the host from oxidative stress (Brading et al. 2000; Guo et al. 2007; Yang et al. 2004). The delicate balance that exists between the ROS toxicity and the ROS signaling network is critical for the oxidative stress response (Beckers and Spoel 2006; Koornneef et al. 2008; Van Breusegem et al. 2008). Higher SA levels in potato may act directly as a preformed antioxidant system to scavenge ROS or modulate the cell redox balance through the activation of antioxidant responses, as has been proposed in rice (Yang et al. 2004). However, we show here that SA itself does not contribute to overall radical-scavenging activity of control plants and the different responses of $N a h G(N b)$ and $\mathrm{Nt}$ $\mathrm{N} \mathrm{Nb}$ ) plants to oxidative stress are due to the function of SA as a molecular signal rather than the chemical properties of SA. As was the case in NahG tomato and NahG rice, in NahG potato, free catechol was undetectable. Thus, free cathecol may not be responsible for the generation of $\mathrm{H}_{2} \mathrm{O}_{2}$ in these plants.

There is also evidence that SA plays a role in regulating plant responses to different environmental stresses and during plant development (Munné-Bosch and Peñuelas 2003; Rao and Davis 1999; Yalpani et al. 1991). Most of the genes regulated by SA are defense-related genes, as such, many participate in plant responses to biotic and abiotic stresses (Dong et al. 2008; Mou et al. 2003). The signal transduction mechanisms involved in the action of SA in these processes and the cross-talk between SA and other signaling molecules have been partially elucidated (Beckers and Spoel 2006; Koornneef et al. 2008; Loake and Grant 2007; Truman et al. 2007).

The effects of SA deficiency on pathogen response in potato have been widely studied with $P$. infestans (Coquoz et al. 1995; Halim et al. 2007; Vleeshouwers et al. 2000; Yu et al. 1997). However, there is little data on activation of SA-dependent defense in response to virus in potato, nor are there data on incompatible potato-virus interaction (Krecic-Stres et al. 2005). PVX ROTH1 elicits cell death in $N b$ potato leaves (Malcuit et al. 1999). We reported previously that the PVX 25$\mathrm{kDa}$ protein is the effector of $N b$-mediated HR (Malcuit et al. 1999). HR lesions that developed on NahG leaves were between three- to fivefold larger in size than those of nontransgenic resistant leaves after first challenge with PVX ROTH1 (Fig. 5A). This observation correlated with the greater virus accumulation in $N a h G(N b)$ leaves compared with $\mathrm{Nt}(\mathrm{Nb})$ plants (Fig. $5 \mathrm{~B})$. Whereas there was no significant accumulation of PVX ROTH1 $C P$ RNA in resistant $N b$ potato plants, the levels of PVX CP RNA rose rapidly to 2.5 -fold higher at $96 \mathrm{~h}$ in $N a h G$ plants during a local resistance response. SAR was induced in $\mathrm{Nt}(\mathrm{Nb})$ potato plants after the first infection with PVX ROTH1, as evidenced by the restriction in viral replication and spread following the second PVX inoculation. (Fig. 5A and B). By contrast, NahG $(\mathrm{Nb})$ potato plants failed to develop SAR (Fig. 5A and B), indicating that SA is involved in $N b$-mediated resistance. However, this phenotype was considerably different from the phenotype observed in tobacco plants constitutively expressing $N a h G$ (Delaney et al. 1994; Gaffney et al. 1993) or Sh isoenzyme (Mur et al. 1997). Following inoculation with Tobacco mosaic virus (TMV), these transgenic plants, both of which contain the $N$ resistance gene, generated HR lesions that grew continually, at times covering the entire leaf, eventually spreading through the stem to reach systemic leaves (Delaney et al. 1994; Mur et al. 1997). In contrast, inoculation of NahG potato plant with PVX ROTH1 generated HR lesions that grew for a limited period of time without spread of symptoms on systemic leaves, indicating that the HR lesions were able to contain the virus (Fig. 5). A similar phenotype was observed in $N a h G T m-2^{2}$ tomato plants inoculated with TMV (Brading et al. 2000). Although our results show that exogenous application of SA is able to restore basal resistance in NahG potato plants, it is not able to restore basal resistance to the levels observed in nontransgenic $\mathrm{Nb}$ potato plants (Fig. 5C and D). As has been reported in other potato cultivars (Coquoz et al. 1995; Yu et al. 1997), nontransgenic resistant Pentland Ivory plants treated with exogenous SA show no difference in lesion size compared with plants without treatment (Fig. 5C), indicating that exogenously applied SA is not able to stimulate resistance to PVX in Nt plants. The high basal SA levels in this cultivar provide a likely explanation for why application of exogenous SA does not enhance resistance to the avirulent strain of PVX. Because the concentration of endogenous SA is great enough in these plants to reach the threshold for triggering a defense response, exogenous application of a greater concentration has no additional impact. Moreover, BTH treatment on $N a h G(\mathrm{Nb})$ potato plants rescues the SA-deficiency phenotype (Fig. 5D), confirming that the loss of SA rather than catechol itself is responsible for the increased susceptibility to PVX.

Our results strongly suggest that the role of SA in potato is not limited to pathogen defense signaling. Rather, SA also influences light acclimation processes and the regulation of the redox homeostasis of the cell. It is likely that SA enhances antioxidant defense activities through induction of enzymatic oxidants, which trigger plant stress responses.

Using the agroinfiltration-mediated assay, we showed that Agrobacterium-based 25K1 expression induced the HR response in an $\mathrm{Nb}$-dependent manner (Fig. 6), demonstrating that this system can be used for the functional complementation analysis of $N b$-resistance gene candidates identified in the $N b$ - $R l$ cluster on chromosome $\mathrm{V}$ of the potato $\mathrm{cv}$. Pentland Ivory (Kuang et al. 2005; M. R. Marano, unpublished date ). In response to $25 \mathrm{~K} 1$ infiltration, the NahG transgenic plants exhibited greater accumulation of ROS as well as more hypersensitive cell death, as determined by measuring the time of apparition and lesion size. Interestingly, $N a h G$ potato leaves also exhibit increased $\mathrm{H}_{2} \mathrm{O}_{2}$ accumulation following exposure to the $25-\mathrm{kDa}$ proteins from the virulent strain UK3 (pBIN25K3).

$N a h G$ and Nt resistant plants show PR-1a expression levels, indicating that $P R-1 a$ expression is SA-independent in $\mathrm{cv}$. Pentland Ivory. In tomato and rice, it has been reported that defense-gene induction is SA-independent (Brading et al. 2000; Yang et al. 2004). NahG rice, as Nt plants, were shown to induce the expression of defense genes $P R-1$ and $P B Z 1$, after inoculation with an avirulent isolate of the fungus Magnaporthe grisea. Brading and associates (2000) analyzed the induction of $P R$ - $1 a$ expression during $C f$-9- and $C f$-2-dependent HR in tomato. They showed that NahG tomato was able to induce $P R-1 a$ expression, although expression was delayed with respect to Nt plants. In contrast, in potato cultivar Désiréé, which is susceptible to $P$. infestans, depletion of endogenous SA was found to correlate with reduced early-defense gene expression (Halim et al. 2007). Similar results were obtained in tobacco and Arabidopsis, in which depletion of endogenous SA typically abolishes or greatly reduces the induction of defense genes during the HR response ( $\mathrm{Bi}$ et al. 1995; Kachroo et al. 2000; Mittler et al. 1999a; Mur et al. 2000).

In Arabidopsis, SA signaling pathways during plant-pathogen interaction involves not only the induction of $P R$ gene expression (Pieterse and Van Loon 2004) but, also, the induction 
of callose synthesis (Dong et al. 2008). $P R$ gene expression and SAR requires the function of NPR1. In the case of induction of callose synthase genes, the regulation of gene expression may be dependent or independent of Nprl (Dong et al. 2008). Previously, we showed that callose deposition is associated with the $N b$-mediated HR elicited by $25 \mathrm{~K} 1$ (Marano et al. 2002). In this work, we found that callose deposition triggered by the $25 \mathrm{~K} 1$ effector is SA dependent.

Defense responses dependent on SA are often effective against biotrophic pathogens, whereas defense dependent on JA are mostly effective against necrotrophic pathogens and insects (Glazebrook 2005). However, recent findings indicate that there is cross-communication between the antagonistic effect of SA and JA signaling, which require the NPR1 protein (Koornneef et al. 2008). NPR1 function and signaling is conserved in both mono- and dicotyledonous plants (Potlakayala et al. 2007), and NPR1 homologs of Arabidopsis thaliana are present in the extensive expressed sequence tag databases of potato (Pajerowska et al. 2005). The wealth of data emerging from sequencing of the potato genome will help us to elucidate distinct signaling pathways induced by different stresses in potato.

\section{MATERIALS AND METHODS}

Plants, construction

of transgenic $N a h G$ potato plants, and growth conditions.

Resistant $(\mathrm{Nb})$ and susceptible $(\mathrm{nb})$ plants were obtained from a selfed progeny of the tetraploid potato cultivar Pentland Ivory carrying the resistance gene $\mathrm{Nb}$ in the simplex condition (Marano et al. 2002). Plants were considered resistant if they displayed HR (necrotic lesions) on leaves mechanically inoculated with PVX avirulent strain ROTH1 and if no virus was detected on systemic leaves. Plants were considered susceptible if, after challenging with ROTH1, the plants became systemically infected with the virus (Marano et al. 2002).

Agrobacterium tumefaciens LBA4404 (Hoekema et al. 1983) was transformed with the binary T-DNA construct SLJ7321, containing the neomycin phosphotransferase gene (npt), the $35 \mathrm{~S}$ promoter of Cauliflower mosaic virus, the SA hydroxylase gene $(N a h G)$ from Pseudomonas putida, and the nopaline synthase termination sequence as described previously (Brading et al. 2000). Transformation into potato cultivar Pentland Ivory $(\mathrm{Nb})$ was performed as described previously (Gilbert et al. 1998). Plants were selected for the $N a h G$ gene using the NPT selectable marker (Brading et al. 2000). Primary transformants were selected for kanamycin $\left(300 \mu \mathrm{g} \mathrm{ml}^{-1}\right)$ resistance. Independently transformed potato lines were propagated on tissue culture medium.

Clonal propagation of potato plants was accomplished by taking a diagonal cut at the level of internodes near the apical meristem. Shoots containing the apical meristem (called 'cuttings') were maintained in water until they formed roots (approximately 2 weeks), at which time they were transferred to soil. The tubers generated by adult plants were stored at $4^{\circ} \mathrm{C}$ until planting. Virus-free potato plants were grown in a greenhouse at 20 to $25^{\circ} \mathrm{C}$ with a $16 \mathrm{~h}$ photoperiod at a light intensity of 150 to $200 \mu \mathrm{E} \mathrm{m}^{-2} \mathrm{~s}^{-1}$.

\section{Viral strains, PVX cDNA clones, and viral inoculation.}

PVX ROTH1 and UK3 were described previously (Malcuit et al. 1999). Potato plants were challenged by sap mechanical inoculation (Marano and Baulcombe 1998). For SAR analysis, potato plants received a first inoculation of PVX on the three lower leaves, whereas uninduced plants received a mock first inoculation with $10 \mathrm{mM} \mathrm{MgCl}_{2}$. At 15 days postinoculation, distal leaves were challenged by a second PVX infection. Vi- rus accumulation in infected potato plants was analyzed by qRT-PCR. Three leaf disks (approximately $60 \mathrm{mg}$ of fresh tissue) per sample were detached from $N a h G(N b)$ and Nt resistant $(\mathrm{Nb})$ and susceptible $(n b)$ plants over a 4-day period postinoculation with PVX ROTH1. Total nucleic acids were extracted using TRIzol reagent (Invitrogen, Carlsbad, CA, U.S.A.), following treatment with RNase-free DNase (Promega, Mannheim, Germany). Reverse transcription was performed by M-MLV reverse transcriptase (Invitrogen) with 2 $\mu \mathrm{g}$ of DNase-treated total RNA and oligo-dT12-18 as primers. Synthesized cDNA was used for qRT-PCR. The reactions were carried out in the presence of the double-stranded DNA-specific dye SYBR green (Invitrogen) and were monitored in real time with the Stratagene MX3005P QPCR system (La Jolla, CA, U.S.A.). Oligonucleotides used in this study, 5'-GCAGCA GCGATTAAAGAGGTGT-3' CP-PVX1 and 5'-GACGTAATT ATGGTGGTGGGAGAG-3' CP-PVX2, rendered 382-bp amplicons. A potato actin amplicon (product size $614 \mathrm{bp}$ ) used as internal standard for quantifications was amplified using $5^{\prime}-\mathrm{GT}$ ATTGTGCTGGATTCTGG-3' (ACT1) and 5'-CTGTTGGAA GGTACTGAGG-3' (ACT2). PCR reactions were performed for 40 cycles according to the following conditions: denaturation at $95^{\circ} \mathrm{C}$ for $15 \mathrm{~s}$, annealing at $55^{\circ} \mathrm{C}$ for $30 \mathrm{~s}$, and extension at $72^{\circ} \mathrm{C}$ for $40 \mathrm{~s}$. After amplification, melting-curve analyses were performed to exclude artefactual amplifications. The relative accumulation of $C P$ PVX ROTH1 was calculated using the threshold cycle values $(\mathrm{Ct})$ obtained from each sample as follows:

relative expression $=2^{-\Delta \Delta}$, being $\Delta \mathrm{Ct}=\mathrm{Ct}_{\mathrm{CP} P V X}-\mathrm{Ct}_{\text {actin }}$ and $\Delta \Delta \mathrm{Ct}=\Delta \mathrm{Ct}_{\mathrm{CP} P V X}-\Delta \mathrm{Ct}_{\text {ref sample }}$.

Inoculation of $\mathrm{MgCl}_{2}$ on potato leaves served as the reference sample, and the results were normalized against actin expression. The average values were calculated from triplicate samples.

\section{Agrobacterium-mediated transient expression.}

The $25 K$ genes of PVX ROTH1 and UK3 were excised as expression cassettes from $\mathrm{p} 25 \mathrm{~K} 1$ and $\mathrm{p} 25 \mathrm{~K} 3$ plasmids (Malcuit et al. 1999) with $K p n I$ and XhoI and were cloned into pBIN19 sites KpnI and SalI (Bevan 1984) to produce pBIN25K1 and pBIN25K3 binary vectors, respectively. Each binary vector was introduced by electroporation into Agrobacterium tumefaciens $\mathrm{C} 58 \mathrm{C} 1$ carrying the virulence helper plasmid pCH32 (Hamilton et al. 1996). Agrobacterium cells transformed with either construct were inoculated into $5 \mathrm{ml}$ of L medium (Sambrook et al. 1989) supplemented with kanamycin at $50 \mu \mathrm{g} \mathrm{ml}^{-1}$ and tetracycline at $5 \mu \mathrm{g} \mathrm{ml}^{-1}$ and were grown at $28^{\circ} \mathrm{C}$ to saturation. Following centrifugation at $750 \times \mathrm{g}$, cells were resuspended in a $5-\mathrm{ml}$ solution containing $10 \mathrm{mM} \mathrm{MgCl}, 10 \mathrm{mM}$ morpholineethanesulfonic acid, $\mathrm{pH}$ 5.6, and $100 \mu \mathrm{M}$ acetosyringone (SigmaAldrich, St. Louis). Agroinfiltration into potato leaves was performed as described previously (Bendahmane et al. 2000; Mestre et al. 2000). Each construct was infiltrated into three cuttings of three resistant $N a h G$ and three susceptible potato plants. HR formation was scored over 3 days postinfiltration.

\section{RNA extraction and RNA gel blot analysis.}

For each sample, total RNA was extracted from three potato leaf disks $1 \mathrm{~cm}$ in diameter, using TRIzol Reagent (Invitrogen) and was subjected to RNA gel blot analysis (Sambrook et al. 1989). RNA gel blots (Hybond-N; Amersham Pharmacia Biotech, Bucks, U.K.) were hybridized with the $\left[\alpha_{-}{ }^{32} \mathrm{P}\right]$ dATPlabeled probes $(N a h G, P R-1 a)$, using standard kit procedure (Amersham Pharmacia Biotech). RNA gel-blot hybridization and membrane washing were performed as described by Sambrook and associates (1989). Hybridization signals were visualized using a Storm 840 Phosphorimager (Amersham Phar- 
macia Biotech). Ethidium bromide $\left(10 \mu \mathrm{g} \mathrm{ml}^{-1}\right)$ was included in the sample-loading buffer, allowing the photographing of the gel after electrophoresis, to confirm equal RNA loading.

\section{SA determinations and treatment of potato leaves.}

SA was extracted from young potato leaves $(500 \mathrm{mg}$ of tissue), and then, was separated and quantified by HPLC, as described previously (Newman et al. 2001). SA concentration was expressed in micrograms per gram of fresh weight.

Potato cuttings were sprayed with $5 \mathrm{mM}$ SA (Sigma-Aldrich) in $15 \mathrm{mM} \mathrm{Na}_{2} \mathrm{HPO}_{4}$, pH 6.5, containing 0.02\% Silwet L-77 (Lehle Seeds, Round Rock, TX, U.S.A.), to reduce surface tension. BTH (Novartis Crop Protection, Basel, Switzerland) was applied as a suspension of the formulated carrier powder (50\% active ingredient) at a concentration of $5 \mathrm{mM}$ in distilled $\mathrm{H}_{2} \mathrm{O}$, containing $0.02 \%$ Silwet L-77. Control plants were sprayed with either $15 \mathrm{mM} \mathrm{Na}_{2} \mathrm{HPO}_{4}$, $\mathrm{pH} 6.5$, or carrier powder solution containing no active $\mathrm{BTH}$; both solutions contained $0.02 \%$ Silwet L-77.

\section{MV treatment and electrolyte leakage analysis.}

MV damage was analyzed using leaf disks as described by Mittler and associates (1999b), modified as follows. Eight potato leaf disks ( $9 \mathrm{~mm}$ diameter) of $N a h G$ and $\mathrm{Nt}$ plants were floated abaxial side up in 2-ml solutions with different concentrations of MV (Sigma-Aldrich). Leaf disks were illuminated with white light $\left(270 \mu \mathrm{E} \mathrm{m}^{-2} \mathrm{~s}^{-1}\right)$ at $22^{\circ} \mathrm{C}$ during different periods of time. The conductivity of the decanted MV solution was determined with an ion conductivity meter (Twin cond B-173; Horiba, Tokyo), referenced as value A. Leaf disks from NahG and Nt plants were autoclaved in MV solutions for $40 \mathrm{~min}$, and conductivity was subsequently measured at room temperature (value B). The percent electrolyte leakage attributable to MV treatment was expressed as percentage of electrolyte leakage ([value A/value B] × 100).

\section{$\mathrm{H}_{2} \mathrm{O}_{2}$ and callose detection.}

Histochemical detection of $\mathrm{H}_{2} \mathrm{O}_{2}$ was carried out as described by Thordal-Christensen and associates (1997). Petioles of potato leaves were placed in an aqueous solution containing $1 \mathrm{mg}$ of DAB per millilter, pH 3.8 (Sigma-Aldrich), and were incubated in Eppendorf tubes for $8 \mathrm{~h}$ at room temperature in the dark. The presence of $\mathrm{H}_{2} \mathrm{O}_{2}$ was visualized as a reddish-brown coloration, due to a precipitate formed by $\mathrm{DAB}$ in the presence of $\mathrm{H}_{2} \mathrm{O}_{2}$. The intracellular $\mathrm{H}_{2} \mathrm{O}_{2}$ was analyzed by the oxidation of DCFH-DA (Sigma-Aldrich), as described by Ezaki and associates (2000). Potato leaves were vacuum-infiltrated with $5 \mu \mathrm{M}$ DCFH-DA. Subsequently, they were washed in phosphatebuffered saline and were viewed with a fluorescence microscope (Olympus model BX50F4, Tokyo). Each experiment (DAB and DCFH-DA) was repeated on at least three different plants, and multiple leaves per plant were examined. Anilineblue staining for the presence of callose deposition in potato leaves undergoing HR was performed as described previously (Marano et al. 2002). Leaves were examined and photographed under white and UV light with a fluorescence microscope (Olympus model BX50F4).

\section{ABTS radical scavenging activity assay.}

The ABTS method was performed according to Pellegrini and associates (1999) with few modifications. ABTS $\bullet^{+}$working solution was prepared as described previously (Pellegrini et al. 1999). Leaf tissues ( $20 \mathrm{mg}$ ) from old and young leaves were collected from $N a h G$ and Nt potato plants, were homogenized in $250 \mu \mathrm{l}$ of methanol, and were incubated $24 \mathrm{~h}$ at $4^{\circ} \mathrm{C}$. Young and old leaves were taken from five $N a h G$ and five control plants with the oldest leaf corresponding to the tenth leaf from the youngest. Leaves of the same age were grouped together to form a sample. The extracts were centrifuged (10 min at $2,000 \times g$ ) and were filtered and stored at $4^{\circ} \mathrm{C}$ in the dark, until use. Aliquots of each sample $(100 \mu \mathrm{l})$ or standard solution were added to $1 \mathrm{ml}$ of methanol. The diluted sample reacted with $2 \mathrm{ml}$ of ABTS $\bullet^{+}$working solution at $30^{\circ} \mathrm{C}$. After 30 min of incubation, decrease in absorbance was measured at $734 \mathrm{~nm}$. The analyses were carried out in triplicate, and the registered activities were compared with those exercised by 2 hydroxy-2,5,7,8-tetramethylchroman-2-carboxilic acid (Trolox) (Sigma, Diesenhofen, Germany), used as standard in the assay. The antioxidant capacity of potato extract leaves was determined by concentration, calculated relative to the reactivity of Trolox. Trolox equivalent antioxidant capacity was defined as the concentration (micromole) of Trolox having the equivalent antioxidant activity per gram of fresh weight tissue.

\section{TLC.}

Extract solutions were prepared as describe above. Standard solutions-30 mM SA (Sigma), $0.5 \mathrm{mM}$ catechol (Sigma), and $2.5 \mathrm{mM}$ chlorogenic acid (Fluka Chemie, Neu-Ulm Germany) were prepared in methanol. TLC was performed on $10 \times 15$ $\mathrm{cm}$ TLC sheets coated with 0.25 -mm layers of silica gel 60 F254 (Merck, Darmstadt, Germany). After application of extracts and standard solution, the sheets were developed as described by Males and Medic-Saric (2001). Visualization of compounds with antioxidant activity present in the methanolic extract of leaves of $N a h G$ and Nt potato cv. Pentland Ivory was achieved by spraying the sheet with a 20 -fold dilution of the $\mathrm{ABTS}^{\bullet}{ }^{+}$stock solution in methanol or $300 \mu \mathrm{M}$ DPPH.

\section{Catechol and SA analysis by GC-MS.}

Frozen leaf tissue $(200 \mathrm{mg})$ from plants 6 to 8 weeks old were powdered in liquid nitrogen and extracted with methanol as describe above. Sorbitol $\left(10 \mu \mathrm{l}\right.$ of a $1 \mathrm{mg} \mathrm{ml}^{-1}$ methanol solution) was added before extraction as an internal standard to correct for differences in extraction efficiency, acetyl derivatization, and changes in sample volume during heating (Morse et al. 2007). The methanolic extracts were centrifuged (10 min at $2,000 \times g$ ), filtrated, and stored at $4^{\circ} \mathrm{C}$ in the dark, until use. The samples were evaporated to dryness under a stream of $\mathrm{N}_{2}$ at $20^{\circ} \mathrm{C}$. For generation of diacetyl derivatives, dried extracts were dissolved in $50 \mu \mathrm{l}$ of pyridine and $100 \mu \mathrm{l}$ of acetic anhydride and were heated for $1 \mathrm{~h}$ at $80^{\circ} \mathrm{C}$ (Engelberth and Engelberth 2009). Derivatized samples $(1 \mu \mathrm{l})$ were injected directly into a Perkin Elmer AutoSystem XL gas chromatograph equipped with a nonpolar VF-1ms (30 $\mathrm{m} \times 0.25 \mathrm{~mm}$ ID, Varian, Walnut Creek, CA, U.S.A.) capillary column. The injector with a split insert was set at $260^{\circ} \mathrm{C}$, and the oven temperature was programmed at $100^{\circ} \mathrm{C}$ for $3 \mathrm{~min}$, and then, ramped at $20^{\circ} \mathrm{C}$ per minute to $310^{\circ} \mathrm{C}$ and maintained at this temperature for $7 \mathrm{~min}$. Gas (helium) flow was set at $1 \mathrm{ml} / \mathrm{min}$ with the injection port configured in the split mode 40:1. The GC was directly interfaced to a Perkin Elmer detector (model TurboMass) with an interface temperature of $280^{\circ} \mathrm{C}$ and ionization by $70 \mathrm{eV}$ electron impact. Positive fragment ions were analyzed in scan range of 40 to $450 \mathrm{Da}$. The quantification was measured using the selected ion recording of 110 for the diacetyl catechol, 120 for the acetyl SA, and 115 for the acetylsorbitol. The data obtained from mass spectrometry and the retention time was compared with standard compounds. All GC and MS parameters were implemented using TurboMass 4.1 software. GC calibration solution $(1,000 \mu \mathrm{l})$ of catechol or SA spanning the concentration range from 0.01 to $100 \mu \mathrm{g} \mathrm{ml}^{-1}$ in methanol solution, and sorbitol $\left(10 \mu \mathrm{l}\right.$ of a $1 \mathrm{mg} \mathrm{ml}^{-1}$ in methanol solution) was added to each tube. After evaporation of the solvent procedures for derivation was followed as described above. 


\section{ACKNOWLEDGMENTS}

This work was supported by the International Foundation for Science (IFS) Ref.: C/3045-1 and the Third World Academy of Sciences (TWAS) Ref.: 99-332 to M. R. Marano. We thank D. Baulcombe for his valuable help and J. Gilbert for the generation of NahG potato plants, M.-A. Newman for her advice in the analysis of SA in potato, M. Hourcade for technical assistance in the GC-MS, and M. Richey for critical review of the manuscript. M. R. Marano and A. A. Vojnov are Career Investigators of the National Scientific and Technical Research Council (CONICET).

\section{LITERATURE CITED}

Asada, K. 1996. Radical production and scavenging in chloroplasts. Pages 123-150 in: Photosynthesis and the Environment. N. R. Baker, ed, Kluwer Academic Publishers, Dordrecht, The Netherlands.

Beckers, G. J. M., and Spoel, S. H. 2006. Fine-tuning plant defence signalling: Salicylate versus jasmonate. Plant Biol. 8:1-10.

Bendahmane, A., Querci, M., Kanyuka, K., and Baulcombe, D. C. 2000. Agrobacterium transient expression system as a tool for the isolation of disease resistance genes: Application to the $R x 2$ locus in potato. Plant $\mathrm{J}$. 21:73-81.

Bevan, M. 1984. Binary Agrobacterium vectors for plant transformation. Nucleic Acids Res. 12:8711-8721.

Bi, Y. M., Kenton, P., Mur, L., Darby, R., and Draper, J. 1995. Hydrogen peroxide does not function downstream of salicylic acid in the induction of PR protein expression. Plant J. 8:235-245.

Brading, P. A., Hammond-Kosack, K. E., Parr, A., and Jones, J. D. 2000. Salicylic acid is not required for $C f-2$ - and Cf-9-dependent resistance of tomato to Cladosporium fulvum. Plant J. 23:305-318.

Bray, E. A., Bailey-Serres, J., and Weretilnyk, E. 2000. Responses to abiotic stresses. Pages 1158-1203 in: Biochemistry and Molecular Biology of Plants. American Society of Plant Physiologists, Rockville, MD, U.S.A.

Coquoz, J.-L., Buchala, A., Meuwly, P., and Métraux, J. P. 1995. Arachidonic acid induces local but not systemic synthesis of salicylic acid and confers systemic resistance in potato plants to Phytophthora infestans and Alternaria solani. Phytopathology 85:1219-1224.

Delaney, T. P., Uknes, S., Vernooij, B., Friedrich, L., Weymann, K., Negrotto, D., Gaffney, T., Gut-Rella, M., Kessmann, H., Ward, E., and Ryals, J. 1994. A central role of salicylic acid in plant disease resistance. Science 266:1247-1250.

Dong, X., Hong, Z., Chatterjee, J., Kim, S., and Verma, D. P. 2008. Expression of callose synthase genes and its connection with Nprl signaling pathway during pathogen infection. Planta 229:87-98.

Durrant, W. E., and Dong, X. 2004. Systemic acquired resistance. Annu. Rev. Phytopathol. 42:185-209.

Engelberth, M. J., and Engelberth J. 2009. Monitoring plant hormones during stress responses. JoVE 28. http://www.jove.com/index/Details. stp?ID=1127, doi: 10.3791/1127.

Ezaki, B., Gardner, R. C., Ezaki, Y., and Matsumoto, H. 2000. Expression of aluminum-induced genes in transgenic Arabidopsis plants can ameliorate aluminum stress and/or oxidative stress. Plant Physiol. 122:657666.

Fobert, P. R., and Despres, C. 2005. Redox control of systemic acquired resistance. Curr. Opin. Plant Biol. 8:378-382.

Gaffney, T., Friedrich, L., Vernooij, B., Negrotto, D., Nye, G., Uknes, S., Ward, E., Kessmann, H., and Ryals, J. 1993. Requirement of salicylic acid for the induction of systemic acquired resistance. Science 261:754756.

Gechev, T. S., Van Breusegem, F., Stone, J. M., Denev, I., and Laloi, C. 2006. Reactive oxygen species as signals that modulate plant stress responses and programmed cell death. BioEssays 28:1091-1101.

Gilbert, J., Spillane, C., Kavanagh, T. A., and Baulcombe, D. C. 1998. Elicitation of $R x$-mediated resistance to PVX in potato does not require new RNA synthesis and may involve a latent hypersensitive response. Mol. Plant-Microbe Interact. 11:833-835.

Glazebrook, J. 2005. Contrasting mechanisms of defense against biotrophic and necrotrophic pathogens. Annu. Rev. Phytopathol. 43:205-227.

Greenberg, J. T., and Yao, N. 2004. The role and regulation of programmed cell death in plant-pathogen interactions. Cell. Microbiol. 6:201-211.

Gülçin, 1., Elmasta, M., and Aboul-Enein, H. Y. 2007. Determination of antioxidant and radical scavenging activity of Basil (Ocimum basilicum $L$. Family Lamiaceae) assayed by different methodologies. Phytother. Res. 21:354-361.

Guo, B., Liang, Y. C., Zhu, Y. G., and Zhao, F. J. 2007. Role of salicylic acid in alleviating oxidative damage in rice roots (Oryza sativa) subjected to cadmium stress. Environ. Pollut. 147:743-749.
Halim, V. A., Eschen-Lippold, L., Altmann, S., Birschwilks, M., Scheel, D., and Rosahl, S. 2007. Salicylic acid is important for basal defense of Solanum tuberosum against Phytophthora infestans. Mol. Plant-Microbe Interact. 20:1346-1352.

Hamilton, C. M., Frary, A., Lewis, C., and Tanksley, S. D. 1996. Stable transfer of intact high molecular weight DNA into plant chromosomes. Proc. Natl. Acad. Sci. U.S.A. 93:9975-9979.

Hoekema, A., Hirsch, P. R., Hooykaas, P. J. J., and Schilperoort, R. A. 1983. A binary plant vector strategy based on separation of vir- and Tregion of the Agrobacterium tumefaciens Ti-plasmid. Nature 303:179180.

Kachroo, P., Yoshioka, K., Shah, J., Dooner, H. K., and Klessig, D. F. 2000. Resistance to turnip crinkle virus in Arabidopsis is regulated by two host genes and is salicylic acid dependent but NPR1, ethylene, and jasmonate independent. Plant Cell 12:677-690.

Koornneef, A., Leon-Reyes, A., Ritsema, T., Verhage, A., Den Otter, F. C., Van Loon, L. C., and Pieterse, C. M. J. 2008. Kinetics of salicylate-mediated suppression of jasmonate signaling reveal a role for redox modulation. Plant Physiol. 147:1358-1368.

Krecic-Stres, H., Vucak, M., Ravnikar, M., and Kovac, M. 2005. Systemic Potato virus $Y^{\text {NTN }}$ infection and levels of salicylic and gentisic acids in different potato genotypes. Plant Pathol. 54:441-447.

Kuang, H., Wei, F., Marano, M. R., Wirtz, U., Wang, X., Liu, J., Shum, W. P., Zaborsky, J., Tallon, L. J., Rensink, W. 2005. The $R 1$ resistance gene cluster contains three groups of independently evolving, type I $R 1$ homologues and shows substantial structural variation among haplotypes of Solanum demissum. Plant J. 44:37-51.

Laloi, C., Apel, K., and Danon, A. 2004. Reactive oxygen signalling: The latest news. Curr. Opin. Plant Biol. 7:323-328.

Lam, E. 2004. Controlled cell death, plant survival and development. Nat. Rev. Mol. Cell Biol. 5:305-315.

Leon, J., Lawton, M. A., and Raskin, I. 1995. Hydrogen peroxide stimulates salicylic acid biosynthesis in tobacco. Plant Physiol. 108:16731678.

Li, J., Shan, L., Zhou, J.-M., and Tang, X. 2002. Overexpression of Pto induces a salicylate-independent cell death but inhibits necrotic lesions caused by salicylate-deficiency in tomato plants. Mol. Plant-Microbe Interact. 15:654-661.

Loake, G., and Grant, M. 2007. Salicylic acid in plant defence-the players and protagonists. Curr. Opin. Plant Biol. 10:466-472.

Malcuit, I., Marano, M. R., Kavanagh, T. A., De Jong, W., Forsyth, A., and Baulcombe, D. C. 1999. The 25-kDa movement protein of PVX elicits $\mathrm{Nb}$-mediated hypersensitive cell death in potato. Mol. Plant-Microbe Interact. 12:536-543.

Males, Z., and Medic-Saric, M. 2001. Optimization of TLC analysis of flavonoids and phenolic acids of Helleborus atrorubens Waldst. et Kit. J. Pharm. Biomed. Anal. 24:353-359.

Marano, M., and Baulcombe, D. C. 1998. Pathogen-derived resistance targeted against the negative-strand RNA of tobacco mosaic virus: RNA strand-specific gene silencing?. Plant J. 13:537-546.

Marano, R., Malcuit, I., De Jong, W., and Baulcombe, C. 2002. High-resolution genetic map of $\mathrm{Nb}$, a gene that confers hypersensitive resistance to potato virus X in Solanum tuberosum. Theor. Appl. Genet. 105:192200.

Mestre, P., Brigneti, G., and Baulcombe, D. C. 2000. An Ry-mediated resistance response in potato requires the intact active site of the NIa proteinase from potato virus Y. Plant J. 23:653-661.

Mittler, R., Herr, E. H., Orvar, B. L., van Camp, W., Willekens, H., Inze, D., and Ellis, B. E. 1999a. Transgenic tobacco plants with reduced capability to detoxify reactive oxygen intermediates are hyperresponsive to pathogen infection. Proc. Natl. Acad. Sci. U.S.A. 96:1416514170.

Mittler, R., Lam, E., Shulaev, V., and Cohen, M. 1999b. Signals controlling the expression of cytosolic ascorbate peroxidase during pathogeninduced programmed cell death in tobacco. Plant Mol. Biol. 39:10251035.

Mou, Z., Fan, W., and Dong, X. 2003. Inducers of plant systemic acquired resistance regulate NPR1 function through redox changes. Cell 113:935-944.

Morse, A. M., Tschaplinski, T. J., Dervinis, C., Pijut, P. M., Schmelz E. A., Day, W. and Davis, J. M. 2007. Salicylate and catechol levels are maintained in $n a h G$ transgenic poplar. Phytochemistry 68:2043-2052.

Muhlenbock, P., Szechynska-Hebda, M., Plaszczyca, M., Baudo, M., Mateo, A., Mullineaux, P. M., Parker, J. E., Karpinska, B., and Karpinski, S. 2008. Chloroplast signaling and LESION SIMULATING DISEASE1 regulate crosstalk between light acclimation and immunity in Arabidopsis. Plant Cell 20:2339-2356.

Munné-Bosch, S. and Peñuelas, J. 2003. Photo- and antioxidative protection, and a role for salicylic acid during drought and recovery in fieldgrown Phillyrea angustifolia plants. Planta 217:758-766. 
Mur, L. A., Bi, Y. M., Darby, R. M., Firek, S., and Draper, J. 1997. Compromising early salicylic acid accumulation delays the hypersensitive response and increases viral dispersal during lesion establishment in TMV-infected tobacco. Plant J. 12:1113-1126.

Mur, L. A., Brown, I. R., Darby, R. M., Bestwick, C. S., Bi, Y. M. Mansfield, J. W., and Draper, J. 2000. A loss of resistance to avirulent bacterial pathogens in tobacco is associated with the attenuation of a salicylic acid-potentiated oxidative burst. Plant J. 23:609-621.

Navarre, D. A., and Mayo, D. 2004. Differential characteristics of salicylic acid-mediated signaling in potato. Physiol. Mol. Plant Pathol. 64:179188

Newman, M.-A., von Roepenack-Lahaye, E., Parr, A., Daniels, M. J., and Dow, J. M. 2001. Induction of hydroxycinnamoyl-tyramine conjugates in pepper by Xanthomonas campestris, a plant defense response activated by $h r p$ gene-dependent and $h r p$ gene-independent mechanisms. Mol. Plant-Microbe Interact. 14:785-792.

Pajerowska, K. M., Parker, J. E., and Gebhardt, C. 2005. Potato homologs of Arabidopsis thaliana genes functional in defense signaling-identification, genetic mapping, and molecular cloning. Mol. Plant-Microbe Interact. 18:1107-1119.

Pellegrini, N., Re, R., Yang, M., and Rice-Evans, C. A. 1999. Screening of dietary carotenoids and carotenoid-rich fruit extracts for antioxidant activities applying the $\mathrm{ABTS}^{+}$radical cation decolorization assay. Methods Enzymol. 299:379-389.

Pieterse, C. M. J., and Van Loon, L. C. 2004. NPR1: The spider in the web of induced resistance signaling pathways. Curr. Opin. Plant Biol. 7:456-464.

Potlakayala, S. D., DeLong, C., Sharpe, A., and Fobert, P. R. 2007. Conservation of NON-EXPRESSOR OF PATHOGENESIS-RELATED GENES1 function between Arabidopsis thaliana and Brassica napus. Physiol. Mol. Plant Pathol. 71:174-183.

Rao, M. V., and Davis, R.D. 1999. Ozone-induced cell death occurs via two distinct mechanisms in Arabidopsis: The role of salicylic acid. Plant J. 17:603-614.

Raskin, I., Skubatz, H., Tang, W., and Meeuse, B. J. D. 1990. Salicylic acid levels in thermogenic and nonthermogenic plants. Ann. Bot. 66:369-373

Sambrook, J., Fritsch, E. F., and Maniatis, T. 1989. Molecular Cloning: A Laboratory Manual, 2nd ed. Cold Spring Harbor Laboratory Press, Cold Spring Harbor, NY, U.S.A.

Schurter, R., Kunz, W. and Nyfelder, R. 1987. EU Patent 0313-512, US Patent 4-931-581.

Shirasu, K., Nakajima, H., Rajasekhar, V. K., Dixon, R. A., and Lamb, C. 1997. Salicylic acid potentiates an agonist-dependent gain control that amplifies pathogen signals in the activation of defense mechanisms. Plant Cell 9:261-270.
Spoel, S. H., and Dong, X. 2008. Making sense of hormone crosstalk during plant immune responses. Cell Host Microbe 3:348-351.

Sroka, Z., and Cisowski, W. 2003. Hydrogen peroxide scavenging, antioxidant and anti-radical activity of some phenolic acids. Food Chem. Toxicol. 41:753-758.

Thordal-Christensen, H., Zhang, Z., Wei, Y., and Collinge, D. B. 1997. Subcellular localization of $\mathrm{H}_{2} \mathrm{O}_{2}$ in plants. $\mathrm{H}_{2} \mathrm{O}_{2}$ accumulation in papillae and hypersensitive response during the barley-powdery mildew interaction. Plant J. 11:1187-1194.

Torres, M. A., Jones, J. D., and Dangl, J. L. (2006). Reactive oxygen species signaling in response to pathogens. Plant Physiol. 141:373-378.

Truman, W., Bennett, M. H., Kubigsteltig, I., Turnbull, C., and Grant, M. 2007. Arabidopsis systemic immunity uses conserved defense signaling pathways and is mediated by jasmonates. Proc. Natl. Acad. Sci. U.S.A. 104:1075-1080.

Van Breusegem, F., Bailey-Serres, J., and Mittler, R. 2008. Unraveling the tapestry of networks involving reactive oxygen species in plants. Plant Physiol. 147:978-984.

Van Wees, S. C., and Glazebrook, J. 2003. Loss of non-host resistance of Arabidopsis NahG to Pseudomonas syringae pv. phaseolicola is due to degradation products of salicylic acid. Plant J. 33:733-742.

Vleeshouwers, V. G. A. A., Van Dooijeweert, W., Govers, F., Kamoun, S., and Colon, L. T. 2000. Does basal PR gene expression in Solanum species contribute to non-specific resistance to Phytophthora infestans? Physiol. Mol. Plant Pathol. 57:35-42.

Wang, D., Amornsiripanitch, N., and Dong, X. 2006. A Genomic approach to identify regulatory nodes in the transcriptional network of systemic acquired resistance in plants. PLoS Path. 2:e123. Published online.

Yalpani, N., Silverman, P., Wilson, T. M., Kleier, D. A., and Raskin, I. 1991. Salicylic acid is a systemic signal and an inducer of pathogenesis-related proteins in virus-infected tobacco. Plant Cell 3:809818.

Yang, Y., Qi, M., and Mei, C. 2004. Endogenous salicylic acid protects rice plants from oxidative damage caused by aging as well as biotic and abiotic stress. Plant J. 40:909-919.

Yu, D., Liu, Y., Fan, B., Klessig, D. F., and Chen, Z. 1997. Is the high basal level of salicylic acid important for disease resistance in potato? Plant Physiol. 115:343-349.

\section{AUTHOR-RECOMMENDED INTERNET RESOURCE}

The Potato Genome Sequencing Consortium (PGSC) home page: www.potatogenome.net 